\title{
Circular Economy Contributions to the Tourism Sector: A Critical Literature Review
}

\author{
Carlos Rodríguez ${ }^{1, *}$, Carmen Florido ${ }^{1}$ and Marta Jacob ${ }^{2}$ (D) \\ 1 Department of Applied Economic Analysis, University of Las Palmas de Gran Canaria, 35017 Las Palmas, Spain; \\ carmen.florido@ulpgc.es \\ 2 Department of Applied Economics, University of the Balearic Islands, E-07122 Palma, Spain; \\ marta.jacob@uib.es \\ * Correspondence: carlos.robaina@ulpgc.es; Tel.: +34-928-458-212
}

Received: 16 April 2020; Accepted: 21 May 2020; Published: 26 May 2020

check for updates

\begin{abstract}
Economic activity today is still based on a linear model of production and consumption: extract/produce and consume/throw, which exhausts natural resources and generates waste. The current linear economy does not optimize materials nor favour their recycling, reuse or recovery. Hence, the concept of Circular Economy (CE) has received increasing attention between policymakers and stakeholders worldwide. However, the literature on CE was mainly developed for the manufacturing sector, and only a few references are found on the tourism sector even though it is a sector where huge consumption of energy and water, food waste, congestion problems and $\mathrm{CO}_{2}$ emissions take place. This work aims to evaluate the importance of tourism in the CE literature and to identify current research trends and possible gaps in the literature on CE and tourism. In order to identify papers for this, the authors carried out a literature review of papers in the social science citation index (Web of Science) and Scopus. The keywords used are related to the tourism sector and CE, and the last search was made at the end of January 2020. Only papers published in English have been considered in the sample, which totals to 55 articles. Each contribution is analysed and, according to its content, classified into eight streams; then, the paper identifies two knowledge areas in tourism that this scientific production covers and the areas with lack of knowledge generated. Findings show that more research is needed about tourism's intersection with CE in order to generate possible solutions towards a more sustainable tourism industry.
\end{abstract}

Keywords: Circular economy; CE principles; circular practices; rural tourism; cultural tourism; maritime sector; renewable energy; resources consumption; sustainable development; waste generation

\section{Introduction}

Nowadays, more resources are being defined as critical, and resource depletion is getting more threatening [1]. Economic activity is still described with a linear model of production and consumption that assumes a take-make-waste pattern in which with energy, labour and capital produce goods and services obtained from natural resources with a single life cycle. Resources are taken from the earth (take), processed into components (make) and, after being used, thrown away (waste). This is called the cradle-to-grave principle [2]. This linear consumption pattern in which the end user is responsible for the removal of the product seemed to be successful in providing affordable products and global welfare but was totally based on waste of resources and the creation of garbage [3].

In light of this, the Circular Economy (CE) has been an object of increasing attention among policymakers, stakeholders and managerial staff in the last few years, becoming a priority in national policies in a growing number of countries. CE appears as an alternative to the current model of production and consumption with the potential of solving environmental challenges, and at the same 
time, it opens up opportunities for business and economic growth. Within a CE society, no waste for disposal should exist; instead, waste should be viewed as a new resource within the economy [4]. Following the CE model, the pressure on the critical resources and the negative effects of disposing of waste can be reduced, whilst reutilization of resources and products can be promoted. Hence, more value can be obtained from the produced resources.

Tourism is an important contributor to employment and GDP in many countries and regions, especially in the EU, where five countries are among the ten best tourism destinations in the world [5]. Tourism also has the potential to contribute to development in rural, peripheral or less developed areas. Indeed, infrastructures created for tourism purposes contribute to local development, while jobs created or maintained can help counteract industrial or rural decline. Nevertheless, tourism also causes significant environmental impacts and can generate great pressure on local resources, producing negative externalities. In addition to land use, it requires resources such as water, energy and food, producing large amounts of waste (solid waste and sewage), as well as congestion on roads, noise and air pollution and, therefore, $\mathrm{CO}_{2}$ emissions [6], and the reason is the linear economy model that we currently follow.

However, the literature on CE was developed mainly for the manufacturing sector, and there are few references to the tourism sector despite the fact that it is an industry predominantly configured around the model of the linear economy. Therefore, many CE solutions can also be applied to tourism businesses and destinations to reverse the trend and reduce consumptions of natural resources, waste and $\mathrm{CO}_{2}$ emissions. However, even recognizing that resources are scarce and limited and that this linear model is no longer viable, in general, the tourism industry has not shown a clear and decisive transition towards a more circular tourism model [7].

Several research questions arise regarding the circular economy and tourism, mainly the following: What is the importance of the field of tourism in the CE literature? What are the current trends of research in CE and tourism? What kind of knowledge is produced? This article presents a comprehensive review on the circular economy and tourism in an attempt to answer these questions.

The aims of this paper are, first, to present a bibliometric review on the circular economy in all fields of research, analysing the importance of $C E$ in the literature, the main journals publishing research on $\mathrm{CE}$ and the research fields where this scientific production is published; second, to analyse the importance of the literature of $\mathrm{CE}$ in tourism and to classify all this scientific literature available on the circular economy and tourism into research streams according to its content and CE principle dealt with; and third, to further develop the model of knowledge needs in tourism of [8] to identify the knowledge areas in tourism that this scientific production on CE and tourism cover and to indicate the areas where new knowledge is needed.

After the introduction, this paper is structured as follows: Section 2 describes the CE background framework, mainly the origin of the CE concept and the importance of the transition from a linear to a circular economy. Section 3 describes the research methodology used for conducting the research. Section 4 provides information about the findings of two bibliometric reviews; Section 4.1 describes the literature review of general documents, conference proceedings and papers on the circular economy in any area indexed in the Web of Science, whereas in Section 4.2, the literature review presented focuses only on specific papers on CE and tourism from the social science citation index (Web of Science) and Scopus. Section 5 presents the discussion of the main results. Finally, the paper concludes with a summary of future fields of research and final remarks on the contribution of this research.

\section{Background Framework}

This section provides a brief introduction to the CE concept, presenting its historical origins, main schools of thoughts and selected definitions. 


\subsection{The Origin of the Circular Economy Concept}

The idea of Circular Economy has received increasing attention within recent years, but the concept is not new. The origin of the concept has been widely discussed, and it cannot be linked to one single date or author, as there are many authors who have written about it. Several schools of thought have analysed, developed and described industrial systems with such features using different terminology and approaches.

The origin of the CE term dates back to the 1920s, through different perspectives and schools of thought. Leontief [9] introduces the concept in his research 'The Economy as a circular flow', Von Bertalanffy [10] developed in 1937 the first breakthrough of 'The general system theory' and Lyle [11] promoted recovery and systems regeneration (materials and energy) through regenerative design.

However, it was at the end of the 1990s when the CE concept was first coined by the environmental economists Pearce and Turner [12] who claim that the term was first used in Western literature in the 1980s to describe a closed system of economy-environment interactions. Stahel and Reday [13] were the first to refer to a closed-loop economy. His idea of improved durability was actually drawn directly from Boulding [14], who wrote: 'I suspect that we have underestimated, even in our spendthrift society, the gains of increased durability'. Greyson [15] also claims that Boulding was the originator of the term when he wrote: 'Man must find his place in a cyclical ecological system which is capable of continuous reproduction of material form even though it cannot escape having inputs of energy' [16]. Another interesting claim is by Robèrt [17], who stated: 'Most environmental problems are based on the same systemic error, linear processing of material. Until resources are processed in cycles, either by society or by biogeochemical processes, the global economy and public health will continue to deteriorate'.

Afterwards, other researchers discussed CE ideas, such as Benyus [18], who talked about biomimicry, McDonough and Braungart [2], in the field of industrial design, or Pauli [19], who wrote about the blue economy. Yuan et al. and Liu et al. [20,21] claimed that it was originally a Chinese concept. More recently, Mathews and Tan [22] suggested that 'the goal of the eco-initiatives is to eventually establish a so-called circular economy or what is otherwise known as a "closed-loop" economy'.

Nowadays, this term has received a great impulse with the work of the Ellen MacArthur Foundation, founded in 2010 in order to spread these innovative ideas and to accelerate the transition towards a circular regenerative and restorative economy. This organization indicates that the generic concept has been refined and developed by the following schools of thought and their authors: Cradle to Cradle, Performance Economy, Biomimicry, Industrial Ecology, Natural capitalism, Blue Economy and Regenerative Design [2,11,13,19,23-25].

Other schools of thought related to the CE concept are Degrowth theory, Economy for the Common Good, Collaborative Economy and Social Economy. Against this background, these schools of thought have a multidisciplinary character reflecting that the circular economy must be analysed from a global point of view where diverse perspectives and approaches interact about its basic principles. Table 1 summarises the information presented in this section.

Once the origin of the CE concept has been analysed, the importance of a change from linear to circular economy will be explained. 
Table 1. Origin of the Circular Economy concept.

\begin{tabular}{ccc}
\hline Year & Author & Topic/School of Thought \\
\hline 1928 & Leontief & 'The Economy as a circular flow' \\
1937 & Von Bertalanffy & 'The general system theory' \\
1966 & Boulding & Improved durability \\
1977 & Stahel and Reday & Performance economy \\
1989 & Frosch and Gallopoulus & Industrial ecology \\
1990 & Pearce and Turner & Closed system of economy-environment interactions \\
1991 & Robèrt & 'Most environmental problems are based on the same systemic \\
1994 & Pauli & error, linear processing of material' \\
1996 & Lyle /regenerative design & Blue economy \\
1997 & Benyus & Regenerative design \\
1999 & Hawken et al. & Biomimicry \\
2002 & McDonough and Braungart & Natural capitalism \\
2011 & Mathews and Tan & Cradle to Cradle \\
\hline
\end{tabular}

\subsection{From Linear to Circular Economy}

Currently, the linear model of production and consumption exhausts the natural resources and generates waste. This model, which assumes that there is an unlimited supply of natural resources and that the environment has an unlimited capacity to absorb waste and pollution, is dismissed [26]. In this context, it seems necessary to find a more holistic model of production that eliminates planned obsolescence through the transformation of 'products' into 'systems', where the equation production cost-environmental damage - product price is optimized, generating environmental benefits, profitability for companies and low prices for consumers.

In view of this, the $\mathrm{CE}$ concept arises, which aims at building a sustainable society through changing the current linear 'take, make and dispose' economy to a closed-loop society where no waste exists [27]. The aim is to implement a new economy, circular and not linear, based on the principle of 'close the cycle of life' of products, services, waste, materials, water and energy, rethinking waste as new resources capable of being reused in the system.

This concept stems from the belief that linear consumption will reach its limits in the foreseeable future $[28,29]$. The belief that linear consumption is reaching its limits originates from the fact that the amount of resources available for use will decline steadily over the next years and decades, leaving little to play with for future use [30,31]. In fact, the linear economy has generated environmental damages, especially in countries that have experienced rapid economic development, such as China [4].

\subsection{Circular Economy: Concept}

Circular Economy as a new economic model has its origins in Environmental Economics, whose aim is the integration of science into sustainability and sustainable development [32].

There are many definitions of the CE concept: Feng et al. [33] described it as a mode of economic development based on ecological circulation of natural materials, requiring compliance with ecological laws and sound utilization of natural resources to achieve economic development; Sauvé et al. [34] defined CE as a model of production and consumption of goods through closed-loop material flows that internalize environmental externalities linked to virgin resource extraction and the generation of waste (including pollution); Hu et al. [35] stated that the focus of the CE is on resource productivity and eco-efficiency improvement, and they adopt the $4 \mathrm{R}$ approach-reduce, reuse, recycle and recover; in addition, Geissdoerfer et al. [36] defined it as a regenerative system in which resource input and waste, emission and energy leakage are minimized by slowing, closing and narrowing material and energy loops. This can be achieved through long-lasting design, maintenance, repair, reuse, remanufacturing, refurbishing and recycling. In its most basic form, a CE can be loosely defined as one which balances economic development with environmental and resource protection [37]. 
Kirchherr et al. [38] gave a broader definition: 'A circular economy describes an economic system that is based on business models which replace the "end-of-life" concept with reducing, alternatively reusing, recycling and recovering materials in production/distribution and consumption processes, thus operational at the micro level (products, companies, consumers), meso level (eco-industrial parks) and macro level (city, region, nation and beyond), with the aim to accomplish sustainable development, which implies creating environmental quality, economic prosperity and social equity, to the benefit of current and future generations'.

More recently, Suárez-Eiroa et al. [39] argue that a circular economy is a regenerative production-consumption system that aims to maintain extraction rates of resources and generation rates of wastes and emissions under suitable values for planetary boundaries, through closing the system, reducing its size and maintaining the resource's value as long as possible within the system, mainly leaning on design and education, and with the capacity to be implemented at any scale.

Given the broad variety of definitions of the CE concept, this paper will focus on the definitions given by the Ellen MacArthur Foundation and the Circle Economy cooperative, which summarizes and gathers all previous definitions mentioned on the CE concept. This Foundation defines CE as an industrial system that is restorative or regenerative by intention and design. It replaces the 'end-of-life' concept with restoration, shifts towards the use of renewable energy, eliminates the use of toxic chemicals, which impair reuse, and aims for the elimination of waste through the superior design of materials, products, systems and, within this, business models [3].

The Ellen MacArthur Foundation has divided the CE definition into principles and characteristics. The principles were developed to be action guides for companies and organizations, whereas the characteristics describe the theoretical CE concept. Ghisellini et al. [40] carried out an extensive review of the CE literature from the late 1990s until mid-2017, and as a result, they state that CE comes out basically through three main actions, the so-called 3R principles: Reduce, Reuse and Recycle.

CE systems intentionally focus on designing products that create no waste and introduce a strict distinction between consumable and durable components. These consist of primarily biological material that can be safely returned to the biosphere when the product reaches its end of life, possibly after the product has gone through a cascading process with multiple phases of reuse and the durable components consist largely of metals and most plastics only embedded in products intentionally designed for reuse [28].

On the other hand, the Circle Economy cooperative describes the CE concepts as closing material loops and mimicking natural ecosystems when regarding society and businesses [41]. Hence, the final goal of CE is to manage and recycle materials efficiently and only use renewable energy without having negative impacts on human life or ecosystems.

According to Kalmykova et al. [42], the dissemination of the circular economy is hampered because the CE field is currently populated by diverging approaches.

Considering all these definitions, we can define CE as an economic model that is interrelated with sustainability concept and whose aim is that the value of products, materials and resources, such as water and energy, stays in the economy as long as possible, thus reducing waste generation. It is about implementing a new economy based on the principle of 'closing the life cycle' of products, services, waste, materials, water and energy, reconsidering waste as a new resource that can be reused in the system. Therefore, the CE implies a radical change in the current production system and consequently in the way of doing of companies, citizens, policymakers and legislators.

\section{Methodology}

In order to identify studies for review, the authors firstly carried out a general review of documents, conference proceedings and papers on circular economy indexed in the Web of Science, followed by a literature review of specific articles and conference proceedings on the circular economy and tourism in two databases: the social science citation index of the Web of Science (Thomson Reuters database), and Scopus. The authors decided to use these two databases because they are the two most important 
databases containing the literature which shows the greatest impact in a particular field, or more than one discipline. In these two reviews, the last search was made at the end of January 2020.

For the general bibliometric review on CE in any field or area, the keyword "circular economy" was searched, and the article parts analysed were first the title, abstract and keywords selected in the paper, and then, we went on with the main text, especially focusing on the findings and conclusions. Only papers published in English were considered for the sample, which totals to 5696 scientific papers. The period scanned for this general review on CE was from 1914 to January 2020.

To analyse the importance of the CE literature in tourism and to classify all this scientific literature available into research streams, the keywords used are related to the tourism sector and circular economy, the topic of this paper, such as hotel, tourism, circular economy, circular tourists, circular hotels, environmental practices, green practices, eco-innovations and so on. Only papers published in English have been considered in the sample, which totals to 55 articles and books. The period considered for this literature review on CE and tourism was from 2009 to January 2020. The selection process of each paper started with an analysis of the title, abstract and keywords selected in the paper (first step to accept the paper for the sample), and then, we went on with the main text, especially focusing on the findings and conclusions (second step to accept/reject the article). All papers were scanned to filter out irrelevant publications. The main reason to reject publications was that they did not really focus on tourism. Subsequently, each contribution was analysed and, according to its content, classified in 8 streams described in the paper.

\section{Findings}

\subsection{General Literature Review on CE}

A literature review was conducted using the keyword 'circular economy' in the Web of Science database. The last search was made at the end of January 2020. Only papers published in English were considered in the sample, which totals to 5696 scientific papers.

Table 2 shows the origin of some of the papers used in this study. The journal that gathers the most papers on CE is the Journal of Cleaner Production with 524 papers, followed by Sustainability with 256 and Resource, Conservation and Recycling with 203 papers. After them, the most important journals are Waste Management New York N Y (116), Waste Management (109), Advanced Material Research (77) and Journal of Industrial Ecology (76), among others. Scientific reports mainly arise from the Ellen MacArthur Foundation [3,30,43], and the European Commission, the EC is currently working on the implementation of the Circular Economy Action Plan [1,27,44,45].

Table 2. Publications on CE by journal (1914-January 2020). Top Eight.

\begin{tabular}{cc}
\hline Source & Count \\
\hline Journal of Cleaner Production & 524 \\
Sustainability & 256 \\
Resources, Conservation and Recycling & 203 \\
Waste Management New York N Y & 116 \\
Waste Management & 109 \\
Advanced Materials Research & 77 \\
Journal of Industrial Ecology & 76 \\
Procedia CIRP & 72 \\
\hline
\end{tabular}

Figure 1 presents the temporal evolution of the papers on CE published per year. As we can observe, $\mathrm{CE}$ is a novel concept within the scientific field, as most of the papers were published after 2006, and 2018 and 2019 being the years with more published papers, with 1009 and 1627, respectively.

Figure 2 presents the number of CE publications by country. As we can observe, in the field of $\mathrm{CE}$ scientific knowledge production, China has the highest number of publications on $\mathrm{CE}$ with 1520 papers published. 


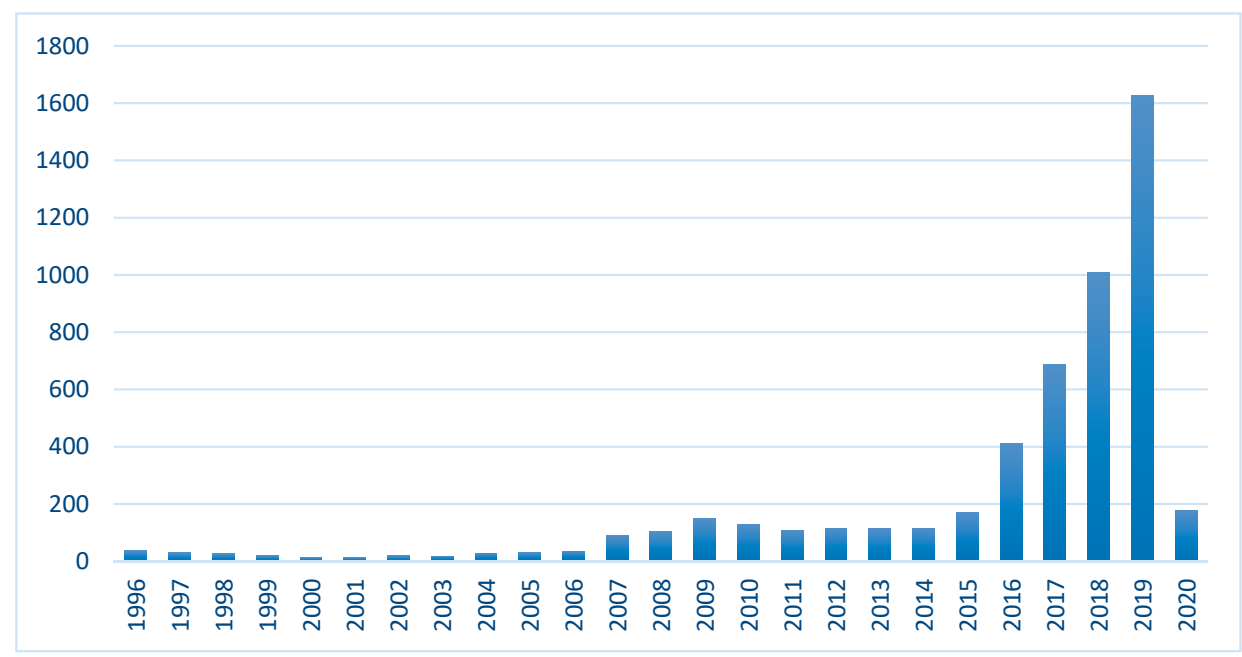

Figure 1. Number of papers published per year.

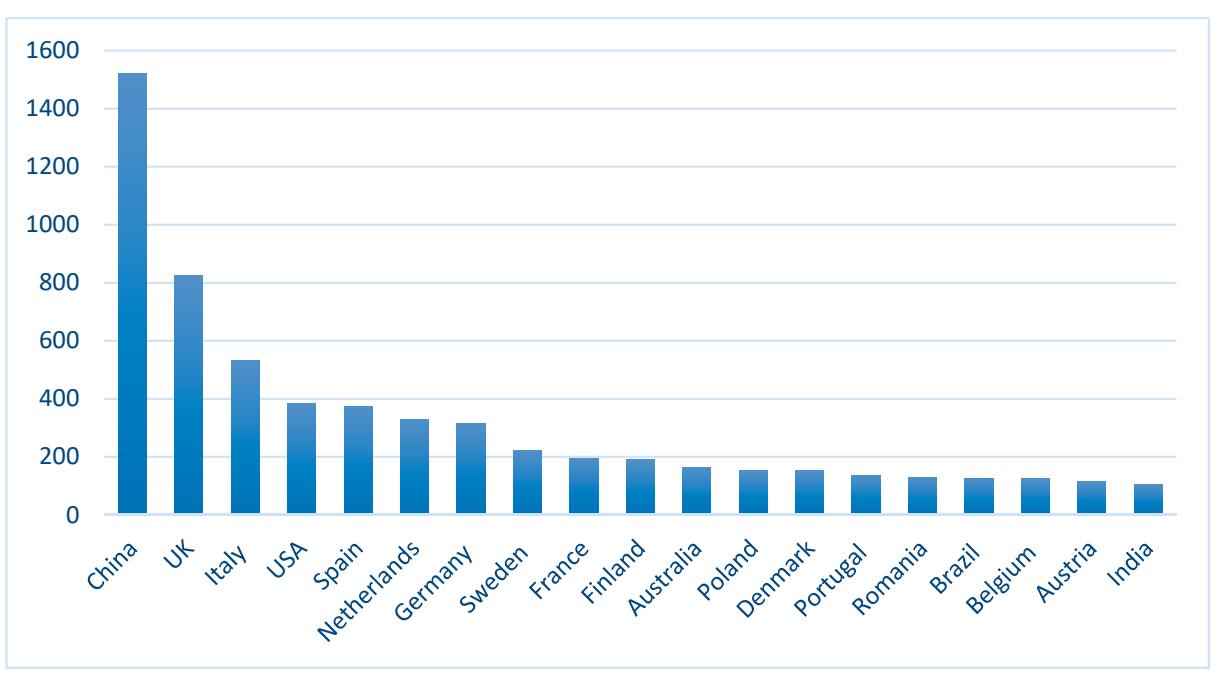

Figure 2. Number of publications by country.

Table 3 presents the papers published on Circular Economy classified by research areas. We can observe that Engineering is the most productive field in terms of published papers, followed by Environmental Sciences and Ecology and then by Business Economics.

Table 3. CE publications by Research Areas.

\begin{tabular}{ccc}
\hline Research Area & Count & Percentage of 5696 Papers \\
\hline Engineering & 3128 & $54.92 \%$ \\
Environmental Sciences and Ecology & 2821 & $49.53 \%$ \\
Business Economics & 2469 & $43.35 \%$ \\
Science Technology Other Topics & 1625 & $28.53 \%$ \\
Energy Fuels & 1567 & $27.51 \%$ \\
Computer Science & 940 & $16.50 \%$ \\
Public Environmental Occupational Health & 696 & $12.22 \%$ \\
Instruments Instrumentation & 653 & $11.46 \%$ \\
Materials Science & 625 & $10.97 \%$ \\
Chemistry & 578 & $10.15 \%$ \\
Agriculture & 525 & $9.22 \%$ \\
Geography & 397 & $6.97 \%$ \\
\hline
\end{tabular}




\subsection{Literature Review on Circular Economy and Tourism}

The literature on CE analysed in Section 4.1 was mainly developed for the manufacturing sector, and it mainly focuses on engineering and science technologies. Only a few references are found in the tourism sector, even so, it is a sector where large consumptions of energy and water, food waste, congestion problems and $\mathrm{CO}_{2}$ emissions and pollution take place.

In effect, the tourism sector has not received much attention in the CE development framework. Naydenov [46] states that the tourism sector has until now not yet received much attention as a possible context for CE initiatives and analyses. However, Vargas-Sánchez [47] argues that this is an area that will deserve much more attention at the international level in the years to come from academics, practitioners and public policymakers.

If we look at the literature, we do not find studies that identify specific guidelines to carry out the transition of the tourism sector towards a circular economy, as it exists in other sectors such as the industrial one. In addition, the flows of resources and materials within the tourism sector intersect with other sectors, which reinforce the need to carry out this transition. Circular tourism implies a model in which each tourism actor (tourist, Destination Management Organizations (DMOs), suppliers (hotels, restaurants, etc.), and resident population) adopts an eco-friendly approach [48].

When a search about this topic (using keywords such as 'circular economy and tourism', 'circular tourism', 'circular tourists', 'hotel and circular economy', 'circular hotels', 'green practices and tourism', 'environmental practices and hotels, tourists or tourism', 'eco-innovations and hotels, tourism or tourists', and so on) is carried out in scientific databases (Web of Science or Scopus), results indicate a scarcity of available literature. The last search was made at the end of January 2020. Only papers published in English have been considered in the sample, which totals to 55 articles and books. Subsequently, each contribution was analysed and, according to its contents, classified into one of the eight streams described in the following section.

The vast majority of the publications found are from Chinese authors; this may be because the government of China has chosen CE as its sustainable development strategy. This strategy, formally accepted in 2002, has been already implemented and developed in a number of pilot areas in the country [49].

Some authors have conducted literature reviews related to the topic of CE and tourism. Niñerola et al. [50] carried out a literature review on sustainability and related concepts through the Scopus database, and they show that there are not many papers related to the keywords 'circular economies' and 'blue economies'. Vargas-Sánchez [47] analyses the state of the art of CE in tourism, and findings show the scarcity of scientific literature available in this field and the lack of a common understanding of this concept. D'Amato et al. [51] carry out a bibliometric review to analyse the diversity within and between Circular Economy, Green Economy (GE) and Bio Economy (BE) concepts. They find, first, that there is a Chinese dominance in CE research; second, that 'CE focuses on industrial urban processes for decoupling resource use and economic output'; and third, that between these concepts, GE is the one where the keyword tourism is more frequently found and analysed. However, none of these reviews classify the publications on circular economy and tourism on research streams or identify current trends in research or the areas where there may be a greater need for research in circular economy and tourism. To fill these gaps, this paper analysed, first, all the publications on circular economy and tourism and classified them into eight streams according to their keywords and the topics covered, as can be seen in Table 4. A few papers can be classified in several streams. Second, the paper further develops the model of knowledge needs in tourism of [8] to identify the knowledge areas in tourism that this scientific production on CE and tourism cover and to indicate the areas where new knowledge is needed on CE and tourism. 
Table 4. Circular economy and tourism by streams.

\begin{tabular}{|c|c|}
\hline \multicolumn{2}{|c|}{ Circular Economy and Tourism } \\
\hline Stream & Keywords \\
\hline Agriculture and rural tourism & $\begin{array}{l}\text { Leisure agriculture, agro-tourism, forestry economy, eco-agriculture, } \\
\text { agro-circular economy, phyto-depuration, fertilizer }\end{array}$ \\
\hline Application of renewable energy in the tourism sector & $\begin{array}{l}\text { Renewable energy, waste-to-energy, low carbon economy, cleaner } \\
\text { production, sustainable energy, smart technology }\end{array}$ \\
\hline Cultural tourism and circular economy & $\begin{array}{l}\text { World heritage sites, cultural urban landscape, alternative tourism, } \\
\text { scenic spots }\end{array}$ \\
\hline Hotels and tourists' circular practices & $\begin{array}{c}\text { Circular hotels, tourists, hotel business case, eco-innovations, hotel } \\
\text { sector's competitiveness, }\end{array}$ \\
\hline Maritime sector and tourism & $\begin{array}{l}\text { Marine debris, marine litter, microplastics, blue growth, maritime } \\
\text { economy, development of seaport cities, aquaculture, seagrasses }\end{array}$ \\
\hline Resources consumption in the tourism sector & Use of resources, environment, infrastructure \\
\hline Sustainable Development Goals & $\begin{array}{c}\text { Sustainable Development Goals, climate change, sustainable jobs, } \\
\text { governance, sustainability }\end{array}$ \\
\hline Tourism and waste generation & $\begin{array}{l}\text { Waste management, septage management, solid-waste management, } \\
\text { secondary raw materials, recycling materials }\end{array}$ \\
\hline
\end{tabular}

\subsubsection{Agriculture and Rural Tourism}

Many of the studies found are focused on agriculture and rural tourism. Jia et al. [52] discuss a development model of leisure agriculture for the Yi County (China) and conclude that it can be used to promote the sustainable development of local ecotourism. Giurea et al. [53] present some preliminary aspects for a comparison between the agro-tourism sectors in Italy and Romania, taking into account the main topics that can affect their sustainability, including the CE concept. Immacolata [54] argues that rural tourism can only be an integrated and coordinated component within integrated rural development models specific for each territory able to ensure a balance between consumption and reproduction of rural collective resources in a new approach to the circular economy. Xuan et al. [55] describe the agro-circular economy concept as the agricultural sustainable development strategy based on the 3-R principle and including green agriculture, ecological agriculture and sustainable agriculture.

$\mathrm{Su}$ et al. [56] expose the connotation of circular economy and ecological agriculture, proposing Rex rabbit industry as an example. They apply cycle of economic theory as a guide to material and energy use optimization for the purpose of using a 4R (Reduce, Reuse, Recycle and Reorganize) principle. Bonanno et al. [57] analyse the application of different methods to achieve sustainable goals in a farm holiday company in Sicily.

Zhang and Tang [58] analyse and evaluate the optimal combination and utilization mode of agricultural and animal husbandry circular economy in mountainous areas in Tibet, taking into account natural resources utilization, agricultural products production and processing, agricultural and animal husbandry production and construction, and eco-tourism development in order to provide better services. They argue that mountain agriculture and animal husbandry leisure tourism mode is an effective way of developing circular practices in rural tourism.

Yuan and Xue [59] study how to construct small towns in a rural area in China based on circular economy to solve environmental problems. The basis for doing this is developing eco-agriculture, eco-industry and eco-service and constructing eco-agricultural areas, eco-industrial areas and eco-tourism areas.

Finally, Kupczyk et al. [60] present a study on the beach wrack problem, which is not only a problematic phenomenon for the environment but also a factor that reduces the tourist attractiveness of the seaside resorts, thus creating a social problem. The use of beach wrack as a fertilizer in agriculture or enrichment of compost will close the circulation of organic matter in the environment, entering the reed bed system into a circular economy.

\subsubsection{Application of Renewable Energy in the Tourism Sector}

Renewable energy plays a key role in the transition towards a CE model in the tourism sector, and many authors have investigated it. Dong [61] argues that using renewable resources instead 
of conventional energy is an important aspect for the application of circular economy in tourism. These renewable energies can be widely used in tourist areas, travel, accommodation, catering, transportation, shopping, entertainment and other tourism enterprises. Falcone [62] complements the current interest towards tourism and circularity principles by doing a Strengths, Weaknesses, Opportunities and Threats-Analytic Network Process (SWOT-ANP) to explore the potential development of a second-generation biorefinery in Salento (Italy) able to integrate waste management, renewable energy and bio-products production in the tourism industry. At the same time, Wu [63] applies a SWOT analysis method to explore the low-carbon economy in Zhaoqing City (China), the optimization of energy structure, the promotion of low-carbon tourism, the development of circular economy, and the enhancement of carbon sink capacity in this city. Additionally, Uche-Soria and Rodríguez-Monroy [64] analyse the potential of municipal solid waste recovery as an efficient alternative to landfill deposition in isolated environments such as the island of La Gomera (Canary Islands), where tourism is the main economic activity. That would be an additional energy source for heat and electricity.

Hens et al. [65] provide a review of essentials that contributed to the fundamental changes in Cleaner Production (CP), indicating the links between $\mathrm{CP}$ and green and circular economy. The tourism sector should use $\mathrm{CP}$ approaches bringing down its carbon footprint and using its inputs more efficiently in order to make the transition to a circular economy. Ma et al. [66] study the renewable energy systems used in tourism circular economy by selecting a scenic spot, and Patti [67] discusses the attitude towards the circular economy and low-carbon tourism by investigating consumption behaviour of people who use sharing utilities. The study also explores motivations to share utilities and the knowledge and sensitivity towards CE. Jaroszewska et al. [68] analyse the CE implementation level in the energy sector of tourist small and medium-sized enterprises (SMEs) in a Polish coastal area, part of the South Baltic Region. They conclude that the tourism sector in the Polish part of South Baltic Region is ready to implement a change from a linear to a circular economy in the context of energy. Finally, Pan et al. [69] provide an overview of the interrelationships between tourism and sustainability, reviewing current challenges and barriers, such as high energy use, extensive water consumption and habitat destruction. They also discuss the key cross-disciplinary elements in sustainable tourism, including green energy, green transportation, green buildings, green infrastructure, green agriculture and smart technologies.

\subsubsection{Cultural Tourism and Circular Economy}

According to [70], cultural tourism represents around 37\% of the total tourism sector, with an annual growth of around $15 \%$. The promotion of the circular economy principles in the rehabilitation and conservation of heritage initiatives is crucial for the sustainable continuity of this sector.

Taking this into account, Fang and Zhang [71] consider that the implementation of CE theory would lead to a long-term protection of world cultural heritage sites in China through the practice of eco-designing, energy conservation, green services facilities provision, waste eco-disposal and green consumption. Valls et al. [72] present Madeira's perception of the slow tourism model, interviewing entrepreneurs in the island's lodging, restaurant and bar, shopping, transportation, intermediation, tourist activity industries and its public sector. In addition, Nocca [73] studies the role that cultural heritage can play in the sustainable development framework with the analysis of 40 case studies of culture-led regeneration projects focusing the attention on the double relationship between the tourism sector and climate change. Results show that cultural heritage conservation/valorisation is mainly interpreted in touristic and real estate impacts. Cultural heritage plays a marginal role in the 2030 Agenda for Sustainable Development as it is only mentioned in the goal 11. Finally, Shi and Zhang [74] state that CE is fundamental to guarantee the promotion of regional economy development and to carry out a sustainable development of scenic spots. 


\subsubsection{Hotels and Tourists' Circular Economy Practices}

Some of the studies analysed focus on the applicability of CE practices and principles in the tourism sector and how to carry out the transition towards a CE model of different international hotel chains or in a tourism destination. For example, Pamfilie et al. [75] state that the application of CE principles can provide hotel companies with the necessary framework for business development and can help to create a more sustainable experience for all stakeholders by reducing the negative implications on social and environmental sustainability. They study the applicability of the CE principles of hotel establishments in Romania from the perspective of industry managers. Rodríguez-Antón and Alonso-Almeida [76] analyse CE practices deployed by four relevant international European hotel chains, identifying their CE strategies and best practices. Similarly, Naydenov [46] presents worldwide examples of circular practices in the tourism sector arguing that hospitality and tourism companies can contribute to sustainable tourism when applying the CE principles, and at the same time, Menegaki [77] studies the published sustainability reports of twenty-five four-star and five-star hotels in Greece to explain how and up to what degree they can be regarded as circular practices.

Florido et al. [48] design guidelines on possible actions and opportunities to carry out a successful transition towards a circular model in hotel companies and describe a model for this transition in a tourist destination. Jones and Wynn [78] examine how a number of academics and companies in the tourism and hospitality industry have used circular economy, natural capital and resilience concepts in their business operations and development plans. Finally, Sørensen et al. [79] report the findings of an exploratory Delphi study whose aim was to identify potential tourist practices for the future development of CE principles in tourism. Findings indicate that there are many possibilities for developing $\mathrm{CE}$ tourist practices.

\subsubsection{Maritime Sector and Tourism}

Around 300 million tons of plastics are produced per year globally [80]. A significant amount of these plastics becomes marine litter. For example, in the Balearic Islands, Martínez-Ribes et al. [81] found that debris contamination was double in summer months (high tourism season) than in low season and that cigarette butts were the most abundant item in high tourist season. These authors state that beach users (mainly tourists in the Balearic Islands with almost 14 million international tourists in 2018, basically concentrated in summer months) are the main source of summer debris.

This problem is studied in several papers. Considering that debris accumulation leads to a decrease of tourism and subsequent income fall, Agamuthu et al. [82] conclude that the long-term sustainable solution to overcome this issue, especially microplastics, would be the adoption of a CE model, and Williams and Rangel-Buitrago [83] provide solutions that can be applied to the marine litter problem, such as, cutting down plastic waste at the source, beach cleanups, use of the circular economy, education and a reduction in packaging.

Paulauskas [84] frames Blue growth by applying Circular Economy 3.00 growth methodology to the maritime sector, presenting a circular model of maritime cluster and describing a circular system of blue growth. Circular economy 3.00 methodology is enabled to frame EU and Blue growth according to five qualitative growth stages: physical, economic, green, sustainable and smart. Ezzat [85] focuses on adopting the CE model in seaports cities as a means to enhance sustainable development, taking the Suez Canal Corridor Project (Egypt) as an example. In addition, Leow and Tan [86] address the environmental and food safety issues of aquaculture through the application of technology across the value-chain of production for cost-effective production and sustainable aquaculture farming. The system provides a perfect platform for the implementation of CE. Eco-tourism opportunities should also be utilized to promote the adoption of these technologies as well as to further public awareness and education in this sector.

Finally, Calvo [87] explains that the beaching of Oceanic Posidonia detritus (banquette) in the Mediterranean Sea can be an environmental, economic and social problem especially for the tourism 
sector and concludes that it has potential applications in the field of Soil Bioengineering. The Reuse of Oceanic Posidonia detritus in the field of Soil Bioengineering is related to one of the 3-R CE principle.

\subsubsection{Resources Consumption in the Tourism Sector}

The tourism sector is dependent on the environment. The environment is an attribute of the product offered, an input of tourism activity, but at the same time, tourism has significant environmental impacts and uses a wide range of natural resources. Taking this into account, two studies have been found related to resource consumption in the province of Catalonia (Spain). Agell et al. [88] identify, classify and analyse 29 key indicators, producing a global adaptation indicator, based on the use of resources and environmental quality, to quantify Catalonia's capacity to adapt to climate change impacts, and Petit-Boix et al. [89] compare the environmental performance of implementing rainwater harvesting (RWH) systems in two neighbourhoods with a water-stressed Mediterranean climate: Calafell (Catalonia), a high-density, tourist city, and Ukiah (California), a typical sprawled area.

Scheepens et al. [90] analyse and design complex circular economy systems using two Life Cycle Assessment (LCA)-based methods. They use the practical case of the analysis, design and implementation of a business model for sustainable water recreation in a province in the Netherlands to validate the usefulness of these two LCA-based methods. Additionally, Fang et al. [91] study how to develop a circular economy and reuse the infrastructure resource in declined mines. As an example, they propose developing a tourism and entertainment industry in the declined mine by making use of the abandoned idle infrastructure resources. Finally, Matarazzo et al. [92] study the environmental impacts of the tourism industry through the life cycle assessment analysis, taking the example of an overnight stay in a hotel of a tourist in Sicily (Italy). The overnight stay in a hotel implies multiple environmental consequences caused by the consumption of specific items such as light bulbs, television, disposable products, air conditioning and electricity in general, as well as the food from the dinner and breakfast.

\subsubsection{Sustainable Development Goals}

Tourism has the potential to contribute to all 17 Sustainable Development Goals (SDGs) approved by the United Nations in 2005 and to be achieved by the year 2030. In particular, tourism has been included as targets in goals 8,12 and 14 on inclusive and sustainable economic growth, sustainable consumption and production, and the sustainable use of oceans and marine resources, respectively [93]. We identify several papers that deal with one or several of these goals. Specifically, Boluk et al. [94] apply a critical lens to the 2030 United Nations Sustainable Development Goals (SDG), using six themes as a conceptual framework for interrogating the SDG agenda in tourism (degrowth and circular economy is one of these themes). Ghosh and Agamuthu [95] propose that countries that have focused on tourism development should consider options for implementing CE principles in sustainable tourism projects. $\mathrm{CE}$ can result in many net benefits and supports achieving the sustainable development goals 2030. At the same time, Girard and Nocca [96] consider the circular tourism sector as its capacity to trigger and stimulate circular flows, aiming to conciliate the tourism sector and sustainable resource management. They present a deep analysis of impacts produced by the tourism sector and its great potential in contributing to the achievement of SDGs.

Calvo et al. [97] highlight some of the current issues and future implications in social and solidarity economy using case studies from around the world and providing an up-to-date account of the strengths and weaknesses of these initiatives including the circular economy. This study is related to goal 8 , so it refers to inclusive and sustainable economic growth. Similarly, goals 8 and 13 on inclusive and sustainable economic growth and action to combat climate change and its impacts, respectively, are related to Viola et al.'s [98] study that reports some examples of sustainable jobs in the tourism sector focusing on environmental aspects. Prideaux and Yin [99] comment on how autonomous vehicles (AVs) may disrupt current forms of tourism mobility because of the climate change problem and suggest an agenda for future research. The tourism industry should be informed of the potential 
for disruption in existing transport mobility patterns and be given time to respond with new products and experiences. This is linked to goals 7 and 13 on sustainable and modern energy and action to combat climate change and its impacts, respectively.

Nocca [73] argues that although the role of cultural heritage in sustainable development has been recognized in the international debate about Sustainable Development Goals (SDGs), it is explicitly mentioned only once in Goal 11. Dong et al. [100] study the current socio-economic and environmental situation of main regions along the China-Mongolia-Russia Economic Corridor and expose the main ecological environment risks, proposing a green development mode to achieve sustainable socio-ecological-economic development of the corridor. This includes the ecological civilization mode, four hierarchies of Chinese circular economy mode, green service industry and low carbon tourism. Finally, Fuldauer et al. [101] argue that evidence-based identification and evaluation of waste management strategies, grounded in participatory processes, can itself contribute to Sustainable Development Goals delivery in Curacao, a tourist island in Venezuela.

\subsubsection{Tourism and Waste Generation}

Regarding waste generation, tourism plays an important role, not only because of the large number of tourists worldwide, but also because of the higher volume of waste per capita of tourists compared to the resident population. According to the European Environment Agency, tourism is responsible for $6.8 \%$ of the waste generated in Europe [102]. In fact, a tourist generates twice more garbage than a resident [103]. Focusing on well-known mature sun and beach tourism destinations in Spain, the Balearic and the Canary Islands lead the classification of autonomous communities in terms of waste production per inhabitant. In the Canary Islands, this percentage rises significantly: if we consider a resident population of 2,106,624 inhabitants and a figure of 14,981,113 tourist arrivals with an average stay of 9.36 days, we obtain that tourists are responsible for $26.7 \%$ of the Canarian waste. Padrón Fumero et al. [104] show that in Tenerife, an additional tourist increases the waste production by $2.97 \mathrm{~kg} /$ day, $1.32 \mathrm{~kg} /$ day higher than that of a resident. Mateu-Sbert et al. [105] estimate that an additional tourist on the island of Menorca generates $1.31 \mathrm{~kg} /$ day of waste, a figure higher than that of a resident.

Noll et al. [106], taking the Greek tourist island of Samothraki as an example, provide an analysis for developing policy and management options for reducing, re-using and recycling of construction and demolition waste on islands where waste treatment options are limited. According to Margeta [107], tourism activities in Croatian islands explain the significant seasonal variability in the amount of wastewater, and in fact, in summer months (high tourism season) it is up to 10 times higher than in winter, creating serious problems for property owners due to uncontrolled disposing of septage, which endangers the environment and human health. Additionally, [107] analyses the problem of septage management in Croatian islands, where tourism is one of the main economic activities, in accordance with the CE framework.

Ragazzi et al. [108] study the recycling program of Trento (a tourist city in Italy), dealing with factors associated with waste recycling, like specific criteria (waste containers selections for door-to-door collection, public awareness and tariff) and solutions (door-to-door bins, warnings, criteria for historic centres). This city reached one of the highest levels of waste-selective collection and waste stream systematization in Italy, being a model for practical solutions and implementation systems for other cities.

Trombin et al. [109] investigate the introduction of affordable technological facilities to treat sludge and the organic fraction of municipal solid waste in the country of Sibiu (Romania), where industrialization and tourism are increasing constantly, while pollution control and the introduction of CE principles are still lacking.

Deselnicu et al. [110] present key elements of the revised waste proposal of the European Commission Circular Economy Package and conclude that a smarter use of resources will help the preservation of essential resources for current and future generations and create synergies for 
industries which mainly depend on it, such as tourism, agriculture and food manufacturing. Finally, Fuldauer et al. [101] propose an integrated methodology for long-term waste management planning to deliver on the United Nations' Sustainable Development Goals in Small Islands Developing States, heavily dependent on tourism, using a national-scale demonstration on Curacao island (Venezuela).

Once all the publications on circular economy and tourism have been classified into streams and analysed, Table 5 presents the main results of each paper by stream and relates it to the $3 R$ Principles of CE.

But what knowledge needs areas does this scientific production contained in Table 5 cover? Jacob et al. [8] propose a model of knowledge needs in tourism, based on the input of tourism activities (tourist, environment, culture). It considers the knowledge needed by the firms and the destination, Destination Management Organizations (DMOs) and key stakeholders. The firm (and the destination) must manage these resources to meet tourist demands, to create wealth and to increase welfare and quality of life in the destination. The model identifies at least four areas of knowledge needs that would benefit from innovations and a fifth one if the need to analyse tourism activity as a generator of wealth is also considered.

When we studied this knowledge production on CE and tourism and relate it to the model of knowledge needs in tourism of [8], we identify that knowledge production on CE and tourism mainly concentrates on generating new knowledge on the environment and on business management, and little knowledge on the culture (Figure 3); however, no new knowledge is generated on the tourist. Hence, there is a gap in the literature.

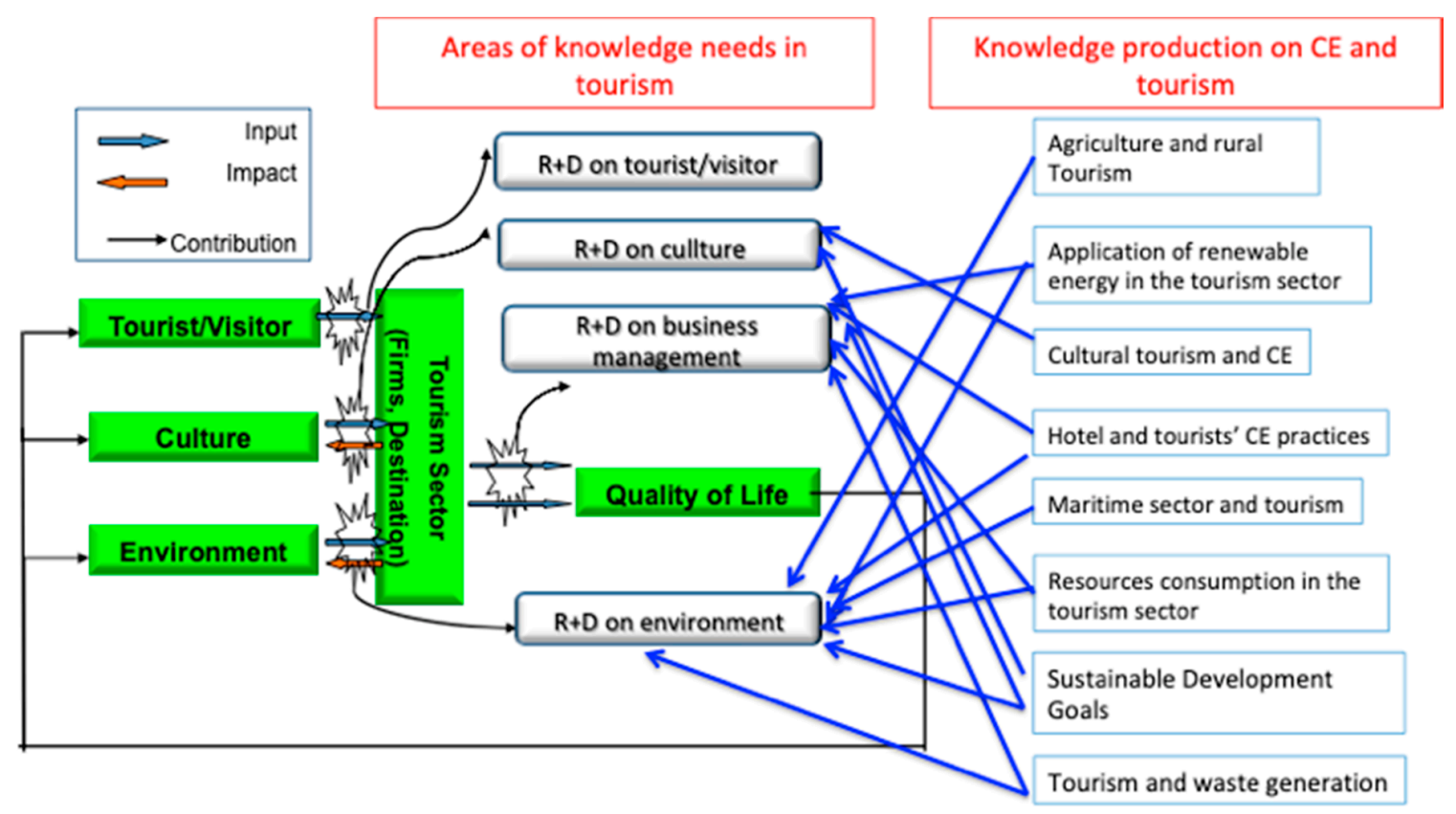

Figure 3. Model of knowledge needs in tourism and correspondence with knowledge production on Circular Economy (CE) and tourism. Source: Elaboration based on [8]. 
Table 5. Circular Economy and Tourism. Research summary.

\begin{tabular}{|c|c|c|c|}
\hline \multicolumn{4}{|c|}{ Circular Economy and Tourism. Research Summary } \\
\hline \multicolumn{4}{|c|}{ Stream 1: Agriculture and rural tourism } \\
\hline Author & Main Results & Policy Implications & 3R Principle \\
\hline Bonanno et al. (2018) & $\begin{array}{l}\text { The farm-holiday company could be considered as a role model for the } \\
\text { territory's enhancement, acting as a driving force for the local economy by } \\
\text { following the green economy principles. }\end{array}$ & To reevaluate and relaunch sustainable tourism in the area. & Reduce and Reuse \\
\hline Giurea, et al. (2017) & $\begin{array}{l}\text { Agro-tourism represents one of the main types of tourism with the highest } \\
\text { potential; its development is for the rural environment a way of } \\
\text { sustainable economic, social and cultural development. }\end{array}$ & $\begin{array}{l}\text { To develop and improve the environmental performance of agro-tourism } \\
\text { activities to ensure an operational framework for agro-tourism managers. }\end{array}$ & Reduce and Recycle \\
\hline Immacolata (2018) & $\begin{array}{l}\text { Rural tourism, today, can only be an integrated and coordinated } \\
\text { component within integrated rural development models specific to } \\
\text { each territory. }\end{array}$ & $\begin{array}{l}\text { To ensure a balance between consumption and reproduction of rural } \\
\text { collective resources, an active participation of all territorial stakeholders in } \\
\text { strategic choices is needed in a new approach to the CE. }\end{array}$ & $3 R$ \\
\hline Jia et al. (2014) & $\begin{array}{l}\text { The development of leisure agriculture can not only reduce the increasing } \\
\text { ecology and humanistic environment pollution and excessive } \\
\text { consumption of resources, but also use local resources fully, extending } \\
\text { industry chain between tourism and agriculture. }\end{array}$ & $\begin{array}{l}\text { Leisure agriculture tourism can help not only to develop new tourism } \\
\text { products but also to promote the development of catering, lodging, } \\
\text { transportation, business and other service industries and to promote the } \\
\text { employment transfer of rural labour and increase farmers' income. }\end{array}$ & $3 R$ \\
\hline Kupczyk et al. (2019) & $\begin{array}{l}\text { The possible use of beach wrack as a fertilizer in agriculture or enrichment } \\
\text { of compost will close the circulation of organic matter in the environment, } \\
\text { thus entering the reed bed system into a CE. }\end{array}$ & $\begin{array}{l}\text { To monitor the beach wrack on the beaches of eutrophicated water } \\
\text { reservoirs, because they cause the return of nutrients to the highly trophic. }\end{array}$ & Reuse \\
\hline Su et al. (2012) & $\begin{array}{l}\text { Cycle of economic theory employment as a guide to material and energy } \\
\text { use optimization for the purpose of using the } 4 \mathrm{R} \text { (Reduce, Reuse, Recycle } \\
\text { and Reorganize) principle. }\end{array}$ & n.a. & $3 R$ \\
\hline Xuan et al. (2011) & $\begin{array}{l}\text { It is urgent to implement agro-circular economy development model: } \\
\text { energy comprehensive utilization pattern, ecological breeding pattern, } \\
\text { agriculture waste comprehensive utilization pattern, agricultural } \\
\text { eco-tourism pattern, etc. }\end{array}$ & $\begin{array}{l}\text { In order to control the agricultural non-point pollution from the source } \\
\text { and build a resource-saving and environment-friendly Erhai ecological } \\
\text { agriculture, an agro-CE model must be implemented. }\end{array}$ & $3 R$ \\
\hline Yuan and Xue (2009) & $\begin{array}{l}\text { The development of small town should depend on its own conditions like } \\
\text { traffic, location, resources and economic characteristics. }\end{array}$ & $\begin{array}{c}\text { Ecological industry system must be completed relying on the strict } \\
\text { scientific management system, thereby getting sustainable development of } \\
\text { a small town. }\end{array}$ & $3 R$ \\
\hline Zhang and Tang (2019) & $\begin{array}{c}\text { According to the 3-R principles, scientific development and construction } \\
\text { will achieve maximum economic benefits and sustainable development of } \\
\text { agriculture and animal husbandry with the least waste and waste } \\
\text { discharge, and make rational and effective use of Tibet's unique rich } \\
\text { natural resources. }\end{array}$ & $\begin{array}{l}\text { It is needed to establish an efficient production system of agriculture and } \\
\text { animal husbandry and to speed up the increase of farmers' and } \\
\text { herdsmen's income to promote the development of regional agriculture } \\
\text { and animal husbandry industry. }\end{array}$ & $3 R$ \\
\hline
\end{tabular}


Table 5. Cont.

\begin{tabular}{|c|c|c|c|}
\hline \multicolumn{4}{|c|}{ Circular Economy and Tourism. Research Summary } \\
\hline \multicolumn{4}{|c|}{ Stream 2: Application of renewable energy in the tourism sector } \\
\hline Author & Main Results & Policy Implications & 3R Principle \\
\hline Dong (2018) & $\begin{array}{l}\text { Renewable energies can be widely used in the tourism cycle economy } \\
\text { system in tourist areas, travel, accommodation, catering, transportation, } \\
\text { shopping, entertainment and other tourism enterprises. }\end{array}$ & $\begin{array}{l}\text { Government support to promote the development of renewable resources } \\
\text { and technology in the development of CE of tourism. }\end{array}$ & Reduce \\
\hline Falcone (2019) & $\begin{array}{l}\text { Results show a higher level of priority for the pressures coming from the } \\
\text { overall external setting involving values, dominant practices, rules and } \\
\text { technologies over the internal tourism industry dynamics. }\end{array}$ & $\begin{array}{l}\text { To reduce the administrative burdens of bureaucracy by introducing, on a } \\
\text { large scale, e-government services, and to promote social awareness } \\
\text { information campaigns. }\end{array}$ & $3 R$ \\
\hline Hens et al. (2018) & $\begin{array}{l}\text { Cleaner production will increasingly become an important part of the } \\
\text { vision, strategy, policy and management not only in production sectors but } \\
\text { also in service sectors as tourism, health care and administration. }\end{array}$ & $\begin{array}{l}\text { A wider and more integrated } \\
\text { approach, combining technological advances with human ecology, } \\
\text { policies, psychology and ethical aspects are mandatory to ensure } \\
\text { sustainable development. }\end{array}$ & $3 R$ \\
\hline Jaroszewska et al. (2019) & $\begin{array}{l}\text { The tourism sector in the Polish part of the South Baltic Region is, at } \\
\text { different levels, ready to implement a change from the linear economy in } \\
\text { the context of energy. }\end{array}$ & $\begin{array}{l}\text { To spread and redistribute 'over-tourism' from the current most popular } \\
\text { cities in South Baltic Region to the less popular smaller towns, rural areas } \\
\text { and villages. }\end{array}$ & $3 R$ \\
\hline Ma et al. (2016) & $\begin{array}{l}\text { Results show the feasibility and availability of the renewable energy } \\
\text { system used in tourism CE. }\end{array}$ & $\begin{array}{l}\text { The use of renewable } \\
\text { resources is an objective requirement of sustainable development in } \\
\text { tourism and an important aspect of tourism CE. }\end{array}$ & $3 R$ \\
\hline Pan et al. (2018) & $\begin{array}{l}\text { The transformation of tourism towards sustainability and a green } \\
\text { economy demands a cross-disciplinary approach to implementation. }\end{array}$ & $\begin{array}{l}\text { Integrative policies, investments in innovative technologies, strong } \\
\text { partnerships between governments and tourism firms and promotion of } \\
\text { green practices are needed. }\end{array}$ & $3 R$ \\
\hline Patti (2017) & $\begin{array}{l}\text { Results confirm the relationship between sharing consumption of goods } \\
\text { and services and attitudes towards CE and circular tourism. }\end{array}$ & $\begin{array}{l}\text { The adoption of new creative models that follow } \mathrm{CE} \text { and sharing } \\
\text { consumption behaviour represent the strategy for a long-run development. }\end{array}$ & $3 R$ \\
\hline $\begin{array}{l}\text { Uche-Soria and } \\
\text { Rodríguez-Monroy (2019) }\end{array}$ & $\begin{array}{l}\text { Evidence on how the practice of recycling and the use of renewable energy } \\
\text { considerably reduce the greenhouse effect. }\end{array}$ & $\begin{array}{c}\text { To implement waste policies for improving the integral management of } \\
\text { municipal solid waste. }\end{array}$ & $3 R$ \\
\hline $\mathrm{Wu}(2019)$ & $\begin{array}{l}\text { Results show that the low-carbon economy concept provides some ideas } \\
\text { for Zhaoqing's (China) economic development. However, its } \\
\text { transportation system is not perfect. }\end{array}$ & $\begin{array}{l}\text { To develop a low-carbon economy, governments, enterprises and } \\
\text { individuals need to participate actively. }\end{array}$ & $3 R$ \\
\hline \multicolumn{4}{|c|}{ Stream 3: Cultural tourism and circular economy } \\
\hline Author & Main Results & Policy implications & 3R Principle \\
\hline Fang and Zhang (2010) & $\begin{array}{l}\text { The overall environmental protection should be paid relatively great } \\
\text { attention during the tourism development process so that the overall } \\
\text { landscape cannot be broken and destroyed. }\end{array}$ & $\begin{array}{l}\text { It is urgent to nurture environment-friendly and low-carbon tourism } \\
\text { products by energy conservation and clean production, source and } \\
\text { terminal pollution control, green goods and infrastructure systems from } \\
\text { industry aspects. }\end{array}$ & Reduce and Reuse \\
\hline Nocca (2017) & $\begin{array}{l}\text { The impacts related to cultural-led projects are mainly interpreted in terms } \\
\text { of tourism and real estate impact. The benefits from cultural heritage } \\
\text { conservation/regeneration are multidimensional. }\end{array}$ & $\begin{array}{l}\text { Design tools to evaluate the contribution of cultural heritage to sustainable } \\
\text { development and to identify a new effective model for sustainable } \\
\text { management of cultural heritage. }\end{array}$ & Reduce and Reuse \\
\hline Shi and Zhang (2013) & $\begin{array}{l}\text { The environmental problems of tourism scenic spots are an important } \\
\text { aspect to guarantee the promotion of regional economic development. }\end{array}$ & To guarantee the promotion of regional economy development. & Recycle and Reuse \\
\hline
\end{tabular}


Table 5. Cont.

\begin{tabular}{|c|c|c|c|}
\hline \multicolumn{4}{|c|}{ Circular Economy and Tourism. Research Summary } \\
\hline \multicolumn{4}{|c|}{ Stream 3: Cultural tourism and circular economy } \\
\hline Author & Main Results & Policy implications & 3R Principle \\
\hline Valls et al. (2019) & $\begin{array}{l}\text { How the application of a slow tourism strategy as a result of an } \\
\text { endogenous drive achieves rapid sustainable development } \\
\text { (Case of Madeira). }\end{array}$ & $\begin{array}{l}\text { To invest in creative and cultural industries, natural and cultural heritage, } \\
\text { and recreational and leisure activities, in order to qualify the tourism area, } \\
\text { encouraging the creation of qualified employment in the sector. }\end{array}$ & Reduce and Recycle \\
\hline \multicolumn{4}{|c|}{ Stream 4: Hotels and tourists' circular practices } \\
\hline Author & Main Results & Policy Implications & 3R Principle \\
\hline Florido et al. (2019) & $\begin{array}{l}\text { Findings identify the main opportunities and benefits of a transition in the } \\
\text { hotel sector and describe a three-axis model to carry out this transition in a } \\
\text { tourism destination. }\end{array}$ & $\begin{array}{l}\text { Governments should focus on defining circular strategies and designing } \\
\text { circular certifications for hotel establishments. }\end{array}$ & $3 R$ \\
\hline Jones and Wynn (2019) & $\begin{array}{l}\text { Some companies use these concepts in their sustainability strategies and } \\
\text { development planning. }\end{array}$ & $\begin{array}{l}\text { To explore how information systems can be better deployed to support } \\
\text { these concepts and sustainability management in general. }\end{array}$ & $3 R$ \\
\hline Menegaki (2018) & $\begin{array}{l}\text { Presentation of systemised information on the state-of-the art of } 254 \text { - and } \\
\text { 5-star hotels in Greece, through the first sustainability databank. }\end{array}$ & $\begin{array}{l}\text { There is a need for targeted policy implementation by central, regional and } \\
\text { municipal governments. }\end{array}$ & $3 R$ \\
\hline Naydenov (2018) & $\begin{array}{l}\text { When applying the CE principles, hospitality and tourism companies can } \\
\text { contribute to sustainable tourism. }\end{array}$ & $\begin{array}{l}\text { Environmental education and the environment are still important for } \\
\text { sustainable development training. }\end{array}$ & $3 \mathrm{R}$ \\
\hline Pamfilie et al. (2018) & $\begin{array}{l}\text { The hotel industry in Romania is not yet sufficiently prepared to adopt the } \\
\text { CE principles, and the adoption of an integrated management system does } \\
\text { not have much influence on the performances of the operators in the field. }\end{array}$ & $\begin{array}{l}\text { Given that the new performance standards go beyond the economic } \\
\text { sphere, social and environmental problems should not be ignored as they } \\
\text { can cause losses for the sector. }\end{array}$ & $3 R$ \\
\hline $\begin{array}{l}\text { Rodríguez-Antón and } \\
\text { Alonso-Almeida (2019) }\end{array}$ & $\begin{array}{l}\text { The main CE strategies adopted by four international hotel chains } \\
\text { analysed are the reduction, recycle and reuse, in this order. }\end{array}$ & $\begin{array}{l}\text { To encourage and support circular tourism among large and small } \\
\text { independent hotels. }\end{array}$ & $3 \mathrm{R}$ \\
\hline Sørensen et al. (2019) & There are many possibilities for developing CE tourist practices. & $\begin{array}{l}\text { More research is needed about tourists' practices and tourism's } \\
\text { intersection with CE in order to facilitate a greater consensus about } \\
\text { possible solutions and ways towards more environmentally } \\
\text { sustainable tourism. }\end{array}$ & Reduce \\
\hline \multicolumn{4}{|c|}{ Stream 5: Maritime sector and tourism } \\
\hline Author & Main Results & Policy Implications & 3R Principle \\
\hline Agamuthu et al. (2019) & $\begin{array}{l}\text { The long-term sustainable solution to overcome marine debris would be } \\
\text { CE. It gives value to waste and promotes reduction in waste generation } \\
\text { owing to implementation of } 3 R \text {. }\end{array}$ & $\begin{array}{l}\text { An urgent, integrated and cooperative effort is required to curb the global } \\
\text { issue of marine debris. }\end{array}$ & $3 R$ \\
\hline Calvo (2018) & $\begin{array}{l}\text { The results confirm the thermal insulation role of Posidonia oceanica and } \\
\text { highlight potential applications in the field of Soil Bioengineering, solving } \\
\text { the problems for the tourism sector. }\end{array}$ & $\begin{array}{l}\text { To raise public awareness of the importance of seagrass and the beached } \\
\text { detritus for the preservation of coastal ecosystems. }\end{array}$ & Reuse \\
\hline Ezzat (2016) & $\begin{array}{l}\text { Both theoretical and empirical best practices stressed the rule of CE } \\
\text { models in supporting sustainable development in seaport cities. }\end{array}$ & $\begin{array}{l}\text { To support some of the dimensions of the } \mathrm{CE} \text { model including the } \\
\text { legislative, institutional and cultural issues. }\end{array}$ & $3 \mathrm{R}$ \\
\hline Leow and Tan (2020) & $\begin{array}{l}\text { Eco-tourism opportunities could be utilized to promote the adoption of } \\
\text { technologies as well as to further public awareness and education in the } \\
\text { aquaculture sector. }\end{array}$ & $\begin{array}{l}\text { The concern over the spread of diseases from escaped farmed fish into the } \\
\text { wild needs to be addressed to ensure the continued viability of } \\
\text { aquaculture farming as a critical food source. }\end{array}$ & $3 R$ \\
\hline
\end{tabular}


Table 5. Cont.

\begin{tabular}{|c|c|c|c|}
\hline \multicolumn{4}{|c|}{ Circular Economy and Tourism. Research Summary } \\
\hline \multicolumn{4}{|c|}{ Stream 5: Maritime sector and tourism } \\
\hline Author & Main Results & Policy Implications & 3R Principle \\
\hline Paulauskas (2018) & $\begin{array}{l}\text { Circular Economy } 3.00 \text { methodology enabled to frame EU and Blue } \\
\text { growth accordingly to clear qualitative growth stages: physical, economic, } \\
\text { green, sustainable and smart. Matrix of growth enabled to recognize and } \\
\text { separate growth features and construct clear prioritized leap of } \\
\text { possible approaches. }\end{array}$ & $\begin{array}{l}\text { Existing amorphous liberal set of possible growth } \\
\text { opportunities must be transferred into a clearly defined target strategy } \\
\text { with a clear understanding of supporting and resisting forces of } \\
\text { Blue growth. }\end{array}$ & Reuse and Recycle \\
\hline $\begin{array}{l}\text { Williams and } \\
\text { Rangel-Buitrago (2019) }\end{array}$ & $\begin{array}{l}\text { Stopping litter generation at the source is the key, which means less waste } \\
\text { is produced; this is vitally important in the production of micro-and } \\
\text { nanoplastics. Product design is also a crucial component. }\end{array}$ & $\begin{array}{l}\text { Marine litter management must be developed within a policy framework } \\
\text { that sets clear objectives and in an institutional environment where } \\
\text { stakeholders have different defined roles. }\end{array}$ & $3 R$ \\
\hline \multicolumn{4}{|c|}{ Stream 6: Resources consumption in the tourism sector } \\
\hline Author & Main Results & Policy Implications & 3R Principle \\
\hline Agell et al. (2016) & $\begin{array}{c}\text { The absolute value of the indicator (from } 0 \text { to 10) dropped slightly } \\
\text { between } 2005 \text { and } 2011 .\end{array}$ & $\begin{array}{l}\text { Catalonia must continue to make every effort to ensure that the land, } \\
\text { natural systems and society are progressively less vulnerable to the } \\
\text { impacts of climate change. }\end{array}$ & $3 R$ \\
\hline Fang et al. (2009) & $\begin{array}{l}\text { The utilization model of infrastructure in a declined mine mainly includes } \\
\text { the model of high-efficiency agriculture, tourism, industrial } \\
\text { transformation, real estate, commerce and store. }\end{array}$ & $\begin{array}{l}\text { It is necessary to adopt } C E \text { principles to reuse the infrastructure resource in } \\
\text { a declined mine. }\end{array}$ & Reduce and Reuse \\
\hline Matarazzo et al. (2018) & $\begin{array}{l}\text { The Life Cycle Assessment (LCA) makes it possible to split the entire } \\
\text { tourism industry into different steps, focusing especially on the analysis of } \\
\text { all the effects created in each phase. }\end{array}$ & $\begin{array}{l}\text { To promote accessibility, availability and free exchange of small and } \\
\text { medium businesses LCA data developing protected, compatible, } \\
\text { transparent and accredited Public Data Banks. }\end{array}$ & Reduce \\
\hline Petit-Boix et al. (2018) & $\begin{array}{c}\text { The implementation of rainwater harvesting was environmentally } \\
\text { beneficial with respect to the business-as-usual scenario. It is more } \\
\text { attractive in Calafell (Spain), a high-density, tourist city, which had 60\% } \\
\text { lower impacts than in Ukiah (US). }\end{array}$ & $\begin{array}{c}\text { Implementing rainwater harvesting could be a viable alternative to meet } \\
\text { water needs in areas with a high building concentration and } \\
\text { water demand. }\end{array}$ & Reduce and Reuse \\
\hline Scheepens et al. (2016) & $\begin{array}{l}\text { The approach of Eco-efficient Value Creation helps to avoid many pitfalls } \\
\text { of the design of circular business models, and the Circular Transition } \\
\text { Framework reveals pitfalls and opportunities in implementation. }\end{array}$ & $\begin{array}{l}\text { Water recreation service must be converted to a sustainable business } \\
\text { model through the introduction of sustainable yachts using renewable } \\
\text { energy and applying sustainable materials. }\end{array}$ & $3 R$ \\
\hline \multicolumn{4}{|c|}{ Stream 7: Sustainable Development Goals } \\
\hline Author & Main Results & Policy Implications & 3R Principle \\
\hline Boluk et al. (2019) & $\begin{array}{l}\text { Results show that degrowth and transitions to a CE present alternative } \\
\text { paradigms under development which provide evidence that there are } \\
\text { viable alternatives to the pervasive pro-growth neoliberal model } \\
\text { of capitalism. }\end{array}$ & $\begin{array}{l}\text { Issues and mechanisms of governance are essential to shape tourism's } \\
\text { future into a form that is equitable, inclusive, just, ecologically compatible } \\
\text { and thereby sustainable. }\end{array}$ & $3 R$ \\
\hline Calvo et al. (2017) & $\begin{array}{l}\text { There is growing interest in social and solidarity economy initiatives, but } \\
\text { research in this area remains scarce. }\end{array}$ & $\begin{array}{l}\text { Social and solidarity economy initiatives need to be more widely } \\
\text { disseminated amongst the general public. }\end{array}$ & $3 R$ \\
\hline Dong et al. (2018) & $\begin{array}{l}\text { Actions to achieve sustainable development of the area include } \\
\text { establishing green, low-carbon, CE system, low carbon eco-tourism pilot } \\
\text { area and cultivating green development and ecological civilization. }\end{array}$ & $\begin{array}{l}\text { To formulate grade circular economic system through the whole process of } \\
\text { production, circulation and consumption, promoting green, circular and } \\
\text { low-carbon development, according to the } 3 \mathrm{R} \text { principle. }\end{array}$ & $3 R$ \\
\hline
\end{tabular}


Table 5. Cont

\begin{tabular}{|c|c|c|c|}
\hline \multicolumn{4}{|c|}{ Circular Economy and Tourism. Research Summary } \\
\hline \multicolumn{4}{|c|}{ Stream 7: Sustainable Development Goals } \\
\hline Author & Main Results & Policy Implications & 3R Principle \\
\hline Fuldauer et al. (2019) & $\begin{array}{l}\text { Results show that the CE strategy outperformed all other strategies with } \\
\text { regard to delivery on SDGs indicators in the low future waste-growth } \\
\text { scenario by } 2030 .\end{array}$ & $\begin{array}{l}\text { To adopt education and awareness campaigns in schools and companies as } \\
\text { well as subsidies for material reuse centres. }\end{array}$ & $3 R$ \\
\hline Ghosh and Agamuthu (2018) & $\begin{array}{l}\text { CE can result in many net benefits and support to achieve the SDGs } 2030 \\
\text { for countries focused on the tourism development. The keys are to define } \\
\text { how to implement CE programmes and what the focus areas should be. }\end{array}$ & $\begin{array}{l}\text { Policies for collaboration between the purchasers and suppliers of } \\
\text { materials to work together and to realize the benefits of a more CE in both } \\
\text { the public and private sectors procurement. }\end{array}$ & $3 R$ \\
\hline Nocca (2017) & $\begin{array}{l}\text { The indicators related to cultural heritage should reveal authenticity, } \\
\text { integrity and cultural values and monitor impacts on the tourism sector, } \\
\text { environmental capital, community well-being, etc. }\end{array}$ & $\begin{array}{l}\text { Indicators have to be used to assess and monitor the state of conservation } \\
\text { of cultural heritage but also to evaluate the impacts of cultural heritage } \\
\text { conservation/regeneration on city multidimensional productivity. }\end{array}$ & Reduce and Reuse \\
\hline Girard and Nocca (2017) & $\begin{array}{c}\text { The tourism sector can represent a threat (because of its negative impacts) } \\
\text { but, at the same time, a starting point in the achievement of sustainable } \\
\text { development. The CE is proposed as a model to operationalize } \\
\text { sustainable principles. }\end{array}$ & $\begin{array}{l}\text { Circular tourism requires appropriate tools, indicators, knowledge and } \\
\text { data in order to assess/monitor the performances of this new model. }\end{array}$ & $3 R$ \\
\hline Prideaux and Yin (2019) & $\begin{array}{l}\text { From a mobility perspective, the introduction of AVs will offer numerous } \\
\text { opportunities for changes in the current flow of domestic and international } \\
\text { tourists within and between destinations. }\end{array}$ & $\begin{array}{l}\text { To introduce legislation that either promotes or hinders the introduction } \\
\text { and rapid adoption of AVs. }\end{array}$ & $3 R$ \\
\hline Viola et al. (2018) & $\begin{array}{c}\text { Education is the strategic and necessary lever towards the creation of } \\
\text { Sustainable Jobs, which lead to the spread of so-called } \\
\text { sustainable employment. }\end{array}$ & $\begin{array}{l}\text { Help to better predict future skills needs, balance better skills and labour } \\
\text { market needs, and bridge the gap between education and employment. }\end{array}$ & $3 R$ \\
\hline \multicolumn{4}{|c|}{ Stream 8: Tourism and waste generation } \\
\hline Author & Main Results & Policy Implications & 3R Principle \\
\hline Deselnicu et al. (2018) & $\begin{array}{l}\text { Smarter use of resources will also help to protect the environment, } \\
\text { preserve essential resources for current and future generations, and create } \\
\text { synergies for industries which most depend on it, such as tourism, } \\
\text { agriculture and food manufacturing. }\end{array}$ & $\begin{array}{l}\text { Clear rules, common standards and support for the use of more secondary } \\
\text { raw materials are necessary to create a safe and sustainable supply of raw } \\
\text { materials to the industry. }\end{array}$ & $3 R$ \\
\hline Fuldauer et al. (2019) & $\begin{array}{l}\text { Evidence-based identification and evaluation of waste management } \\
\text { strategies, grounded in participatory processes, can itself contribute to } \\
\text { SDGs delivery in Curacao (Venezuela). }\end{array}$ & $\begin{array}{l}\text { To implement laws which restrict certain tourism-generated waste streams } \\
\text { which cannot be dealt with locally. }\end{array}$ & $3 R$ \\
\hline Margeta (2019) & $\begin{array}{l}\text { Due to tourism activities the amount of wastewater in Croatian islands } \\
\text { seasonally varies considerably and in summer is up to } 10 \text { times higher } \\
\text { than in winter. }\end{array}$ & $\begin{array}{l}\text { The EU legal framework requires that organic waste be disposed of in } \\
\text { accordance with the CE principles }\end{array}$ & Reuse and Recycle \\
\hline Noll et al. (2019) & $\begin{array}{l}\text { The material stock expanded from } 175 \mathrm{t} / \mathrm{cap} \text { to } 350 \mathrm{t} / \mathrm{cap} \text { in the period } \\
\text { between } 1971 \text { and 2016, leading to a 15-fold increase of annual } \\
\text { Construction and Demolition Waste (CDW) generation. }\end{array}$ & $\begin{array}{l}\text { To inform the stakeholders of any construction project on discarding } \\
\text { options for CDW. } \\
\text { The management of CDW should be based on a collective waste } \\
\text { management system to work on reuse, recycling or processing. }\end{array}$ & $3 R$ \\
\hline Ragazzi et al. (2017) & $\begin{array}{l}\text { Trento community reached one of the highest levels of waste-selective } \\
\text { collection and waste stream systematization in Italy, being as such a model } \\
\text { for practical solutions and implementation systems for other cities. }\end{array}$ & $\begin{array}{l}\text { The framing of eco-citizenship, legislation, municipalities, parties and } \\
\text { good coordinators of the afferent financial loop can lead to reliable waste } \\
\text { management schemes. }\end{array}$ & $3 R$ \\
\hline Trombin et al. (2017) & $\begin{array}{l}\text { The organic fraction full stream collection seems to be the only way to } \\
\text { have a significant energy recovery. }\end{array}$ & $\begin{array}{l}\text { From the financial point of view, the feasibility of this co-treatment option } \\
\text { could count on specific opportunities for Romania within the EU context. }\end{array}$ & Reuse and Recycle \\
\hline
\end{tabular}




\section{Discussion}

Despite the importance of tourism as a catalyst for the global economy, it also causes significant environmental impacts and generates great pressure on local resources, producing negative externalities due to the current use of linear economy production models; hence, we need to change to CE production models. However, the literature on CE was developed mainly for the manufacturing sector, and there are few references on the tourism sector.

The purpose of this article was to describe and classify the scientific literature about CE and tourism. To this end, the authors firstly carried out a general review of circular economy in documents, conference proceedings and papers indexed in the Web of Science, followed by a literature review of specific articles only on CE and tourism in the social science citation index (Web of Science) and Scopus. The general review shows that the literature on $\mathrm{CE}$ was mainly developed for the manufacturing sector, it totals to 5696 scientific papers, and it mainly focuses on engineering and science technologies. For the specific review on tourism and $\mathrm{CE}$, the keywords used are related to the tourism sector and circular economy, and the last search was made at the end of January 2020, providing a sample of 55 articles and books. Each contribution found was analysed and, according to its contents, classified into eight research streams. The main results and policy implications of all papers contained in each research stream are presented, as well as the $3 R$ principles of $C E$ dealt with in each paper.

Results show that:

- Stream 1 gathers $16.36 \%$ of total papers; analysis indicates that the implementation of CE actions in agriculture is vital to achieving sustainability in the sector. Agro-tourism is an effective way of developing circular practices in rural tourism.

- Stream 2 gathers $16.36 \%$ of all papers on CE and tourism; literature shows that renewable energy plays a key role in the transition towards a CE model in the tourism sector. Using renewable resources instead of conventional energy is an important aspect for the application of tourism circular economy.

- Stream 3 collects $7.27 \%$ of all papers. This stream shows that the promotion of CE principles in the rehabilitation and conservation of heritage initiatives is crucial for the sustainable continuity of cultural tourism.

- Stream 4 gathers $12.73 \%$ of all papers in CE and tourism; literature indicates that the application of CE principles can provide hotel companies with the necessary framework for business development and can help to create a more sustainable experience for all stakeholders by reducing the negative implications on social and environmental sustainability.

- Stream 5 collects $10.91 \%$ of all literature. Considering that debris accumulation leads to a decrease of tourism and subsequent income fall, the long-term sustainable solution to overcome this issue, especially microplastics, would be the adoption of a CE model. Solutions such as cutting down plastic waste at the source, beach clean-ups, use of the $\mathrm{CE}$, education and a reduction in packaging should be implemented. On the other hand, CE model implementation helps to achieve the sustainable development of seaport cities.

- Stream 6 gathers $9.09 \%$ of all papers studied; this stream leads to the conclusion that tourism has significant environmental impacts and uses a wide range of natural resources, and hence, it is crucial to use the resources taking into account CE principles in order to minimize the negative impact on the environment.

- Stream 7 represents $16.36 \%$ of all literature available on CE and tourism. The main conclusion is that tourism has the potential to contribute to all 17 Sustainable Development Goals (SDGs). It can represent a threat (because of its negative impacts), but at the same time, a starting point in the SDGs achievement; and, finally,

- Stream 8 gathers $10.91 \%$ of total papers. Regarding waste generation, tourism plays an important role, not only because of the large number of tourists worldwide but also because of the higher volume of waste per capita of tourists compared to the resident population. A smarter use of 
resources will help to preserve essential resources for current and future generations and to create synergies for industries dependent on it, such as tourism, agriculture and food manufacturing.

Additionally, most of the papers focus on the $3 R$ principles: $21.82 \%$ on $2 \mathrm{R}$ of the $3 \mathrm{R}$ principles and $9.09 \%$ on only one of the $3 \mathrm{R}$ principles. This scientific production on $\mathrm{CE}$ and tourism mainly covers knowledge needs on the environment and business management. No knowledge is generated on the tourist, for example, on how to attract tourists to a circular hotel, circular tourist business or to a circular destination, or on the profile of the most sensitive customers to circular initiatives. Furthermore, no knowledge has been generated in this literature on developing circular certifications for hotels, tourism businesses or for a destination.

\section{Conclusions}

As previously mentioned, there are some gaps identified in the literature on CE and tourism, such as the lack of evidence on how to make the transition to a CE model in the tourism sector or the lack of knowledge generated on the tourist and CE. Literature mainly focuses on the construction, energy and water consumption, reutilization and new uses, and less on other relevant aspects, such as the need for a change in the business model, reuse of organic waste and synergies with agriculture, circularity of tourist destinations, the application of $\mathrm{CE}$ as a model to achieve sustainable development of the local economy through synergies with tourism or the use of $\mathrm{CE}$ as a model to achieve inclusive and sustainable tourism with local development.

$\mathrm{CE}$ is a crucial way to contribute to a more sustainable tourism industry. The tourism industry has a significant role to play because of its importance in the global economy. Therefore, it is urgent to have a joint and multidisciplinary response in order to achieve a successful transition to a CE model in the tourism sector. The involvement of all academics, tourists, resident population, public administrations and DMOs is required.

Regarding agriculture and rural tourism, we need to develop and to improve the environmental performance of agro-tourism activities to relaunch and promote sustainable tourism in a new approach to the CE.

Governments should promote the development and use of renewable energies in order to achieve a more sustainable tourism, and policy strategies should aim at reducing the administrative burdens of bureaucracy. Governments, tourism firms and individuals need to participate actively, and information campaigns could increase the degree of social awareness in the sector for the transition to a CE model.

The hotel sector is a major consumer of resources and a generator of waste. Therefore, governments need to support circular tourism and focus on defining circular strategies and designing circular certifications for hotel establishments. In addition, tourists have to be aware of the importance of this transition to a CE model. Awareness programs for tourists should be designed, and hotels should advertise their good environmental practices to their guests.

Waste generation is a very important aspect to take into account due to the large amount of waste generated by the tourist sector. Laws and common rules to reduce waste generation in the tourism sector need to be designed and implemented. Hotels can carry out some actions to reduce their waste generation, such as composting organic waste, prioritizing repair over replacement or offering closed menus at restaurants to reduce food waste, among others. Focusing on the global issue of marine litter, an integrated and cooperative effort is required by all stakeholders in order to reduce its accumulation on the coasts.

To sum up, more research is needed about the tourism intersection with CE in order to generate possible solutions towards a more sustainable tourism industry. As we have seen, it is a relatively young field of research. The literature review shows that most studies have been conducted over the past 25 years. This is an emerging field of study, with increasing numbers of researchers focusing on it. Therefore, further empirical work and research are needed to improve our understanding of CE in tourism. Future research could focus on defining a global circular strategy that involves all tourism sector actors and areas, on how to attract tourists to a circular hotel or destination, or on identifying 
the profile of the most sensitive customers to circular initiatives. Furthermore, another future line of research could be the development of circular certifications for hotels, tourism businesses or for a destination.

Finally, the main limitations of this study are that we have considered only papers and studies published in English in the two databases analysed. Hence, some literature on CE and tourism published in another language is not considered. Moreover, conference papers (not indexed by Web of Science nor Scopus) or reports published from European projects on CE have not been included in this review, although they can provide important contributions to this relatively new field of research.

Author Contributions: Conceptualization, C.R., C.F. and M.J.; methodology, C.R., C.F. and M.J.; validation, C.F., and M.J.; formal analysis, C.R.; investigation, C.R., C.F. and M.J.; data curation, C.R.; writing-original draft preparation, C.R., C.F. and M.J.; writing-review and editing, C.F. and M.J.; supervision, C.F. and M.J.; project administration, C.R., C.F. and M.J.; funding acquisition, C.F. and M.J. All authors have read and agreed to the published version of the manuscript.

Funding: This research was founded by Mac-ISLANDAP project (Mac/1.1a/207), financed by the Operational Programme of Territorial Cooperation MAC 2014-2020 with ERDF funds.

Conflicts of Interest: The authors declare no conflict of interest.

\section{References}

1. European Commission. Report on Critical Raw Materials for the EU. Available online: https:/ec.europa.eu/ info/index_en (accessed on 15 November 2019).

2. McDonough, W.; Braungart, M. Cradle to Cradle: Remaking the Way We Make Things; North Point Press: New York, NY, USA, 2010.

3. Ellen MacArthur Foundation. Towards the Circular economy, Opportunities for the Consumer Goods Sector. Available online: https://www.ellenmacarthurfoundation.org/ (accessed on 20 November 2019).

4. Geng, Y.; Doberstein, B. Developing the circular economy in China: Challenges and opportunities for achieving 'leapfrog development'. Int. J. Sustain. Dev. World Ecol. 2008, 15, 231-239. [CrossRef]

5. World Tourism Organization. UNWTO Tourism Highlights. 2017 Edition. Available online: https://www.unwto.org/ (accessed on 22 November 2019).

6. Rico, A.; Arenas-Sánchez, A.; Alonso-Alonso, C.; López-Heras, I.; Nozal, L.; Rivas-Tabares, D.; Vighi, M. Identification of contaminants of concern in the upper Tagus river basin (central Spain). Part 1: Screening, quantitative analysis and comparison of sampling methods. Sci. Total Environ. 2019, 666, 1058-1070. [CrossRef]

7. Manniche, J.; Larsen, K.T.; Broegaard, R.B.; Holland, E. Destination: A Circular Tourism Economy A Handbook for Transitioning Toward a Circular Economy within the Tourism and Hospitality Sectors in the South Baltic Region; Centre for Regional \& Tourism Research (CRT): Bornholm, Denmark, 2017.

8. Jacob, M.; Florido, C.; Payeras, M. Knowledge production in two mature destinations. Ann. Tour. Res. 2014, 48, 280-284. [CrossRef]

9. Leontief, W. Die Wirtschaft als Kreislauf. ASwSp 1928, 60, 577-623.

10. Von Bertalanffy, L. General System Theory; George Brazilier: New York, NY, USA, 1968; pp. 3-17.

11. Lyle, J.T. Regenerative Design for Sustainable Development; John Wiley \& Sons: New York, NY, USA, 1996.

12. Pearce, D.; Turner, R.K. Economics of natural resources and the environment, Hemel Hempstead: Harvester Wheatsheaf. In Natural Resource and Environmental Economics, 3rd ed.; Perman, R., Ma, Y., McGilvray, J., Common, M., Eds.; Longman: Harlow, UK, 2003.

13. Stahel, W.R.; Reday, G. The Potential for Substituting Manpower for Energy; Report to DG V for Social Affairs;(Research Contract No. 760137 Programme of Research and Actions on the Development of the Labour Market), Study, (76/13); Commission of the EC: Brussels, Belgium, 1977.

14. Boulding, K.E. The Economics of Coming Spaceship Earth. In Environmental Quality in a Growing Economy; Jarrett, H., Ed.; John Hopkins Press: Baltimore, MD, USA, 1966; pp. 3-14.

15. Greyson, J. An economic instrument for zero waste, economic growth and sustainability. J. Clean. Prod. 2007, 15, 1382-1390. [CrossRef]

16. Murray, A.; Skene, K.; Haynes, K. The circular economy: An interdisciplinary exploration of the concept and application in a global context. J. Bus. Ethics 2017, 140, 369-380. [CrossRef] 
17. Robèrt, K.H. The physician and the environment. Reviews in Oncology. Eur. Organ. Res. Treat. Cancer 1991, $4,1-3$.

18. Benyus, J.M. Biomimicry: Innovation Inspired by Nature; William Morrow: New York, NY, USA, 1997; p. 308.

19. Pauli, G.A. The Blue Economy: 10 Years, 100 Innovations, 100 Million Jobs; Paradigm Publications: Taos, NM, USA, 2010.

20. Yuan, Z.; Bi, J.; Moriguichi, Y. The circular economy: A new development strategy in China. J. Ind. Ecol. 2006, 10, 4-8. [CrossRef]

21. Liu, Q.; Li, H.-M.; Zuo, X.-L.; Zhang, F.-F.; Wang, L. A survey and analysis on public awareness and performance for promoting circular economy in China: A case study from Tianjin. J. Clean. Prod. 2009, 17, 265-270. [CrossRef]

22. Mathews, J.A.; Tan, H. Progress towards a circular economy in China: The drivers (and inhibitors) of eco-industrial initiative. J. Ind. Ecol. 2011, 15, 435-457. [CrossRef]

23. Benyus, J. A Good Place to Settle: Biomimicry, Biophilia, and the Return of Nature's Inspiration to Architecture; Biophilic Design: The Theory, Science, and Practice of Bringing Buildings to Life; Wiley: Hoboken, NJ, USA, 2008.

24. Frosch, R.A.; Gallopoulos, N.E. Strategies for manufacturing. Sci. Am. 1989, 261, 144-153. [CrossRef]

25. Hawken, P.; Lovins, A.; Lovins, L. Natural Capitalism: Creating the Next Industrial Revolution; Little, Brown and Co.: Boston, MA, USA, 1999.

26. Cooper, T. Creating an economic infrastructure for sustainable product design. J. Sustain. Prod. Des. 1999, 8, 7-18.

27. European Commission. The Circular Economy-Connecting, Creating and Conserving Value. Available online: https://ec.europa.eu/info/index_en (accessed on 15 November 2019).

28. Ellen MacArthur Foundation. Towards the Circular Economy; Economic and Business Rationale for an Accelerated Transition. Available online: https://www.ellenmacarthurfoundation.org/ (accessed on 20 November 2019).

29. Van Dijk, S.; Tenpierik, M.; Van Den Dobbelsteen, A. Continuing the building's cycles: A literature review and analysis of current systems theories in comparison with the theory of cradle to cradle. Resour. Conserv. Recycl. 2014, 82, 21-34. [CrossRef]

30. Ellen MacArthur Foundation. Accelerating the Scale-Up Across Global Supply Chains. Available online: https://www.ellenmacarthurfoundation.org/ (accessed on 22 November 2019).

31. Mentink, B. Circular Business Model Innovation: A Process Framework and a Tool for Business Model Innovation in a Circular Economy; Delft University of Technology: Delft, The Netherlands, 2014.

32. Andersen, M.S. An introductory note on the environmental economics of the circular economy. Sustain. Sci. 2007, 2, 133-140. [CrossRef]

33. Feng, W.J.; Mao, Y.R.; Chen, H.; Chen, C. Study on development pattern of circular economy in chemical industry parks in China. Xiandai Huagong/Mod. Chem. Ind. 2007, 27, 7-10.

34. Sauvé, S.; Bernard, S.; Sloan, P. Environmental sciences, sustainable development and circular economy: Alternative concepts for trans-disciplinary research. Environ. Dev. 2016, 17, 48-56. [CrossRef]

35. Hu, J.; Xaio, Z.; Deng, W.; Wang, M.; Ma, S. Ecological utilization of leather tannery waste with circular economy model. J. Clean. Prod. 2011, 19, 221-228. [CrossRef]

36. Geissdoerfer, M.; Savaget, P.; Bocken, N.M.; Hultink, E.J. The Circular Economy-A new sustainability paradigm? J. Clean. Prod. 2017, 143, 757-768. [CrossRef]

37. UNEP. Circular Economy: An Alternative Model for Economic Development. United Nations Environment Programme. Available online: https://www.unenvironment.org/ (accessed on 10 December 2019).

38. Kirchherr, J.; Reike, D.; Hekkert, M. Conceptualizing the circular economy: An analysis of 114 definitions. Resour. Conserv. Recycl. 2017, 127, 221-232. [CrossRef]

39. Suárez-Eiroa, B.; Fernández, E.; Méndez-Martínez, G.; Soto-Oñate, D. Operational principles of circular economy for sustainable development: Linking theory and practice. J. Clean. Prod. 2019, 214, 952-961. [CrossRef]

40. Ghisellini, P.; Cialani, C.; Ulgiati, S. A review on circular economy: The expected transition to a balanced interplay of environmental and economic systems. J. Clean. Prod. 2015, 114, 1-22. [CrossRef]

41. Circle Economy. About Circular Economy. Available online: https:/www.circle-economy.com/ (accessed on 8 December 2019). 
42. Kalmykova, Y.; Sadagopan, M.; Rosado, L. Circular economy-From review of theories and practices to development of implementation tools. Resour. Conserv. Recycl. 2018, 135, 190-201. [CrossRef]

43. Ellen MacArthur Foundation. Circularity Indicators-An Approach to Measure Circularity. Available online: https://www.ellenmacarthurfoundation.org/ (accessed on 28 November 2019).

44. European Commission. Circular Economy Strategy. Available online: https://ec.europa.eu/info/index_en (accessed on 25 November 2019).

45. European Commission. Circular Economy: New Regulation to BOOST the Use of Organic and Waste-Based Fertilisers. Available online: https://ec.europa.eu/info/index_en (accessed on 25 November 2019).

46. Naydenov, K. Circular tourism as a key for eco-innovations in circular economy based on sustainable development. In Proceedings of the International Multidisciplinary Scientific GeoConference: SGEM: Surveying Geology \& Mining Ecology Management, Albena, Bulgaria, 30 June 2018; Volume 18, pp. $135-141$.

47. Vargas-Sánchez, A. The unavoidable disruption of the circular economy in tourism. Worldw. Hosp. Tour. Themes 2018, 10, 652-661. [CrossRef]

48. Florido, C.; Jacob, M.; Payeras, M. How to Carry out the Transition towards a More Circular Tourist Activity in the Hotel Sector. The Role of Innovation. Adm. Sci. 2019, 9, 47. [CrossRef]

49. Su, B.; Heshmati, A.; Geng, Y.; Yu, X. A review of the circular economy in China: Moving from rhetoric to implementation. J. Clean. Prod. 2013, 42, 215-227. [CrossRef]

50. Niñerola, A.; Sánchez-Rebull, M.V.; Hernández-Lara, A.B. Tourism research on sustainability: A bibliometric analysis. Sustainability 2019, 11, 1377. [CrossRef]

51. D’Amato, D.; Droste, N.; Allen, B.; Kettunen, M.; Lähtinen, K.; Korhonen, J.; Leskinen, P.; Matthies, B.D.; Toppinen, A. Green, circular, bio economy: A comparative analysis of sustainability avenues. J. Clean. Prod. 2017, 168, 716-734. [CrossRef]

52. Jia, Z.; Qin, A.; Jia, H. Research on the development of leisure agriculture tourism in Yi County based on circular economy. Manag. Eng. 2014, 15, 72.

53. Giurea, R.; Ioan, A.M.; Ragazzi, M.; Cioca, L.I. Focusing agro-tourism structures for environmental optimization. Qual. Access Success 2017, 18, 115-120.

54. Immacolata, V. Agriculture, rural tourism and circular paradigm. Qual. Access Success 2018, 19, 556-562.

55. Xuan, L.I.; Baotong, D.E.N.G.; Hua, Y.E. The research based on the 3-R principle of agro-circular economy model-the Erhai lake basin as an example. Energy Procedia 2011, 5, 1399-1404. [CrossRef]

56. Su, H.; Tan, D.; Gao, Y.; Liu, J. Research on Eco-Industrial Development and league mechanism construction of Breeding Industry. J. Converg. Inf. Technol. 2012, 7, 19.

57. Bonanno, S.; Amato, F.; Silluzio, C.; Trimarchi, E.G.; Matarazzo, A.; Bentivegna, G. Smart and circular economy applied to a Sicilian company as a sewage treatment model. Procedia Environ. Sci. Eng. Manag. 2018, 5, 21-28.

58. Zhang, H.G.; Tang, X.Y. Study on optimized combination and utilization model of agricultural and animal husbandry resources in mountain ecotone. In Proceedings of the Conference Series: Earth and Environmental Science, Volume 346, 5th International Conference on Agricultural and Biological Sciences (ABS), Macau, China, 21-24 July 2019; Volume 346, p. 012031.

59. Yuan, Q.; Xue, X. The eco-industrial system study of circular small town. In Proceedings of the 16th International Conference on Industrial Engineering and Engineering Management, Beijing, China, 21-23 October 2009; pp. 1636-1639.

60. Kupczyk, A.; Kołecka, K.; Gajewska, M.H. Solving the Beach Wrack Problems by On Site Treatment with Reed Beds Towards Fertilizer Amendments. J. Ecol. Eng. 2019, 20, 252-261. [CrossRef]

61. Dong, Q. Study on the Development Strategy of Tourism Circular Economy Based on Renewable Energy Technology. J. Ad. Oxid. Technol. 2018, 21, 2.

62. Falcone, P.M. Tourism-Based Circular Economy in Salento (South Italy): A SWOT-ANP Analysis. Soc. Sci. 2019, 8, 216. [CrossRef]

63. Wu, W. Modern urban planning and design based on low carbon economy concept. Open House Int. 2019, 44, 108-111.

64. Uche-Soria, M.; Rodríguez-Monroy, C. An Efficient Waste-To-Energy Model in Isolated Environments. Case Study: La Gomera (Canary Islands). Sustainability 2019, 11, 3198. [CrossRef] 
65. Hens, L.; Block, C.; Cabello-Eras, J.J.; Sagastume-Gutierez, A.; Garcia-Lorenzo, D.; Chamorro, C.; Mendoza-Herrera, K.; Haeseldonckx, D.; Vandecasteele, C. On the evolution of "Cleaner Production" as a concept and a practice. J. Clean. Prod. 2018, 172, 3323-3333. [CrossRef]

66. Ma, X.; Li, S.; Ai, Q.; Chen, K. Research on renewable energy systems used in tourism circular economy. In Proceedings of the 2016 Chinese Control and Decision Conference, Yinchuan, China, 28-30 May 2016; pp. 6203-6206.

67. Patti, S. Circular economy and sharing consumption: Attitudes towards low-carbon tourism. Econ. Policy Energy Environ. 2017, 16, 219-234. [CrossRef]

68. Jaroszewska, M.; Chaja, P.; Dziadkiewicz, A. Sustainable energy management: Are tourism SMEs in Poland ready for circular economy solutions? Int. J. Sustain. Energy Plan. Manag. 2019, 24, 75-83.

69. Pan, S.Y.; Gao, M.; Kim, H.; Shah, K.J.; Pei, S.L.; Chiang, P.C. Advances and challenges in sustainable tourism toward a green economy. Sci. Total Environ. 2018, 635, 452-469. [CrossRef] [PubMed]

70. World Tourism Organization UNWTO. Tourism and Culture Synergies. Available online: https://www. unwto.org/ (accessed on 12 January 2020).

71. Fang, X.; Zhang, X. On Tourism Environment Protection for World Cultural Heritage Sites in China. In Proceedings of the International Conference on Management and Service Science, Wuhan, China, 24-26 August 2010; pp. 1-4.

72. Valls, J.F.; Mota, L.; Vieira, S.C.F.; Santos, R. Opportunities for Slow Tourism in Madeira. Sustainability 2019, 11, 4534. [CrossRef]

73. Nocca, F. The role of cultural heritage in sustainable development: Multidimensional indicators as decision-making tool. Sustainability 2017, 9, 1882. [CrossRef]

74. Shi, C.; Zhang, G. The ecological construction of scenic spots. Biotechnol. Indian J. 2013, 8, 1306-1310.

75. Pamfilie, R.; Firoiu, D.; Croitoru, A.G.; Ionescu, G.H.I. Circular Economy-A New Direction for the Sustainability of the Hotel Industry in Romania? Amfiteatru Econ. 2018, 20, 388-404.

76. Rodríguez-Antón, J.M.; Alonso-Almeida, M.D.M. The Circular Economy Strategy in Hospitality: A Multicase Approach. Sustainability 2019, 11, 5665. [CrossRef]

77. Menegaki, A.N. Economic aspects of cyclical implementation in Greek sustainable hospitality. Int. J. Tour. Policy 2018, 8, 271-302. [CrossRef]

78. Jones, P.; Wynn, M.G. The circular economy, natural capital and resilience in tourism and hospitality. Int. J. Contemp. Hosp. Manag. 2019, 31, 2544-2563. [CrossRef]

79. Sørensen, F.; Bærenholdt, J.O.; Greve, K.A.G.M. Circular economy tourist practices. Curr. Issues Tour. 2019, 1-4. [CrossRef]

80. Plastics Europe. Plastics-The Facts. An Analysis of European Plastics Production, Demand and Waste Data. Available online: https://www.plasticseurope.org/en (accessed on 15 November 2019).

81. Martínez-Ribes, L.; Basterretxea, G.; Palmer, M.; Tintoré Subirana, J. Origin and abundance of beach debris in the Balearic Islands. Sci. Mar. 2007, 71, 305-314. [CrossRef]

82. Agamuthu, P.; Mehran, S.B.; Norkhairah, A.; Norkhairiyah, A. Marine debris: A review of impacts and global initiatives. Waste Manag. Res. 2019, 37, 987-1002. [CrossRef] [PubMed]

83. Williams, A.T.; Rangel-Buitrago, N. Marine Litter: Solutions for a major environmental problem. J. Coast. Res. 2019, 35, 648-663. [CrossRef]

84. Paulauskas, S. Blue Growth Circular Innovation. Transnav-Int. J. Mar. Navig. Saf. Sea Transp. 2018, 12, 813-818. [CrossRef]

85. Ezzat, A.M. Sustainable development of seaport cities through circular economy: A comparative study with implications to Suez Canal corridor project. Eur. J. Sustain. Dev. 2016, 5, 509-522. [CrossRef]

86. Leow, B.T.; Tan, H.K. Technology-Driven Sustainable Aquaculture for Eco-tourism. In Proceedings of the WCFS2019, Singapore, 22-23 April 2019; pp. 209-218.

87. Calvo, R. Thermal insulation role and possible exploitation of Posidonia oceanica detritus in the Mediterranean area. Flora Mediterr. 2018, 28, 279-285. [CrossRef]

88. Agell, E.; Ambatlle, F.; Borràs, G.; Cantos, G.; Samitier, S. A Global Indicator of Climate Change Adaptation in Catalonia. In Implementing Climate Change Adaptation in Cities and Communities; Springer: Cham, Switzerland, 2016; pp. 191-202. 
89. Petit-Boix, A.; Devkota, J.; Phillips, R.; Vargas-Parra, M.V.; Josa, A.; Gabarrell, X.; Rieradevall, J.; Apul, D. Life cycle and hydrologic modeling of rainwater harvesting in urban neighborhoods: Implications of urban form and water demand patterns in the US and Spain. Sci. Total Environ. 2018, 621, 434-443. [CrossRef]

90. Scheepens, A.E.; Vogtländer, J.G.; Brezet, J.C. Two life cycle assessment (LCA) based methods to analyse and design complex (regional) circular economy systems. Case: Making water tourism more sustainable. J. Clean. Prod. 2016, 114, 257-268. [CrossRef]

91. Fang, X.; De-shan, T.; Ying-de, L. Study on the utilization model of infrastructure in declined mine based on the circular economy. In Proceedings of the 2009 International Conference on Sustainable Power Generation and Supply, Nanjing, China, 6-7 April 2009; pp. 1-4.

92. Matarazzo, A.; Maugeri, E.; Gullo, E.; Romano, P.; Spedalieri, F.; Licciardello, A. The Bioeconomy in Sicily: New Green Marketing Strategies Applied to the Sustainable Tourism Sector. In Proceedings of the Global Conference on Business, Hospitality, and Tourism Research (GLOSEARCH 2018), Ho Chi Minh City, Vietnam, 2-5 October 2018.

93. World Tourism Organization UNWTO. Tourism and the Sustainable Development Goals. Available online: https://www.unwto.org/ (accessed on 13 January 2020).

94. Boluk, K.A.; Cavaliere, C.T.; Higgins-Desbiolles, F. A critical framework for interrogating the United Nations Sustainable Development Goals 2030 Agenda in tourism. J. Sustain. Tour. 2019, 27, 847-864. [CrossRef]

95. Ghosh, S.K.; Agamuthu, P. Circular economy: The way forward. Waste Manag. Res. 2018, 36, 481-482. [CrossRef]

96. Girard, L.F.; Nocca, F. From linear to circular tourism. Aestimum 2017, 70, 51-74.

97. Calvo, S.; Morales, A.; Zikidis, Y. Social and Solidarity Economy: The World's Economy with a SOCIAL Face; Routlege: London, UK, 2017.

98. Viola, I.; Simonetti, B.; Öztürk, L. Sustainable jobs and tourism. Riv. Di Studi Sulla Sostenibilita' 2018, 2, 45-56. [CrossRef]

99. Prideaux, B.; Yin, P. The disruptive potential of autonomous vehicles (AVs) on future low-carbon tourism mobility. Asia Pac. J. Tour. Res. 2019, 24, 459-467. [CrossRef]

100. Dong, S.; Li, Y.; Li, Z.; Li, F.; Cheng, H.; Yang, Y.; Bilgaev, A.; Zheng, J.; Bazarzhapov, T. Ecological environment risks and green development modes of China-Mongolia-Russia economic corridor. In Proceedings of the IOP Conference Series: Earth and Environmental Science, Irkutsk, Russia, 20-26 August 2018; IOP Publishing: Bristol, UK, 2018; Volume 190, p. 012053.

101. Fuldauer, L.I.; Ives, M.C.; Adshead, D.; Thacker, S.; Hall, J.W. Participatory planning of the future of waste management in small island developing states to deliver on the Sustainable Development Goals. J. Clean. Prod. 2019, 223, 147-162. [CrossRef]

102. EEA. European Environment, State and Outlook 2010; EEA: Copenhagen, Denmark, 2010; ISBN 978-92-9213-155-5. Available online: http://www.ab.gov.tr/files/ardb/evt/1_avrupa_birligi/1_6_raporlar/1_3_diger/environment/ eea_2010_the_european_environment_synthesis.pdf (accessed on 9 January 2020).

103. González Camazón, C. La Fiscalidad Verde. Creación de nuevos tributos sobre emisiones y residuos. Bachelor's Thesis, University of Valladolid, Valladolid, Spain, 12 July 2016.

104. Padrón Fumero, N.; Castellanos Nieves, D.; Díaz Fariña, E. Los determinantes de la generación de residuos sólidos municipales en los municipios y destinos turísticos: El caso de la isla de Tenerife. In Proceedings of the AECIT 2016, Tenerife, Spain, 16-18 November 2016.

105. Mateu Sbert, J.; Ricci-Cabello, I.; Villalonga Olives, E.; Cabeza-Irigoyen, E. The impact of tourism municipal solid waste generation: The case of Menorca Island (Spain). Waste Manag. 2013, 12, 2589-2593. [CrossRef]

106. Noll, D.; Wiedenhofer, D.; Miatto, A.; Singh, S.J. The expansion of the built environment, waste generation and EU recycling targets on Samothraki, Greece: An island's dilemma. Resour. Conserv. Recycl. 2019, 150, 104405. [CrossRef]

107. Margeta, J. A review of sustainable septage management strategies on the islands in Croatia. Water Sci. Technol. 2019, 79, 1833-1843. [CrossRef]

108. Ragazzi, M.; Fedrizzi, S.; Rada, E.C.; Ionescu, G.; Ciudin, R.; Cioca, L.I. Experiencing Urban Mining in an Italian Municipality towards a Circular Economy vision. Energy Procedia 2017, 119, 192-200. [CrossRef] 
109. Trombin, G.; Ragazzi, M.; Isarie, C.; Ciudin, R.; Torretta, V. Environmental assessment of the Sibiu County, Romania: Proposal for sewage sludge and OFMSW management. In Proceedings of the MATEC Web Conference, Sibiu, Romania, 7-9 June 2017; EDP Sciences: Les Ulis, France, 2017; Volume 121, p. 10006.

110. Deselnicu, D.C.; Militaru, G.; Deselnicu, V.; Zainescu, G.; Albu, L. Towards a Circular Economy-A Zero Waste Programme for Europe. In Proceedings of the 7th ICAMS, Bucarest, Romania, 18-20 October 2018; pp. 563-569.

(c)

(C) 2020 by the authors. Licensee MDPI, Basel, Switzerland. This article is an open access article distributed under the terms and conditions of the Creative Commons Attribution (CC BY) license (http://creativecommons.org/licenses/by/4.0/). 